\title{
Timing and depositional environments of a Middle Pleistocene glaciation of northeast England: New evidence from Warren House Gill, County Durham
}

\author{
B.J. Davies ${ }^{a, b, *}$, D.H. Roberts ${ }^{a}$, D.R. Bridgland ${ }^{a}, C . O^{\prime}$ Cofaigh ${ }^{a}$, J.B. Riding ${ }^{c}$, B. Demarchi ${ }^{d}$, K.E.H. Penkman ${ }^{d}$, \\ S.M. Pawley
}

a Department of Geography, Durham University, Science Laboratories, South Road, Durham, DH1 3LE, UK

${ }^{b}$ Centre for Glaciology, The Institute of Geography and Earth Sciences, Aberystwyth University, Llandinam Building, Penglais Campus, Aberystwyth, SY23 3DB, UK

'British Geological Survey, Kingsley Dunham Centre, Keyworth, Nottingham, NG12 5GG, UK

${ }^{d}$ BioArCh, Departments of Biology, Archaeology and Chemistry, University of York, York, YO10 5DD, UK

e Department of Geography, Royal Holloway, University of London, Egham, Surrey, TW20 OEX, UK

\begin{abstract}
At various times during the Quaternary, north-eastern England was a zone of confluence between dynamic ice lobes sourced from the Pennines, northern Scotland, the Cheviots, and Scandinavia. The region thus has some of the most complex exposures of Middle to Late Pleistocene sediments in Britain, with both interglacial and glacial sediments deposited in terrestrial and marine settings. We investigated sedimentary sequences exposed on the coastline of County Durham at Warren House Gill, and present a new model of British and Fennoscandian Ice Sheet interaction in the North Sea Basin during the Middle Pleistocene.

The stratigraphy at Warren House Gill consists of a lower diamicton and upper estuarine sediments, both part of the Warren House Formation. They are separated from the overlying Weichselian Blackhall and Horden tills by a substantial unconformity. The lower diamicton of the Warren House Formation is re-interpreted here as an MIS 8 to 12 glaciomarine deposit containing ice-rafted lithics from north-eastern Scotland and the northeast North Sea, and is renamed the 'Ash Gill Member'. It is dated by lithological comparison to the Easington Raised Beach, Middle Pleistocene Amino Acid Racemisation values, and indirectly by optically stimulated luminescence. The overlying shallow subaqueous sediments were deposited in an estuarine environment by suspension settling and bottom current activity. They are named the 'Whitesides Member', and form the uppermost member of the Warren House Formation. During glaciation, ice-rafted material was deposited in a marine embayment. There is no evidence of a grounded, onshore Scandinavian ice sheet in County Durham during MIS 6, which has long been held as the accepted stratigraphy. This has major implications for the currently accepted British Quaternary Stratigraphy. Combined with recent work on the Middle Pleistocene North Sea Drift from Norfolk, which is now suggested to have been deposited by a Scottish ice sheet, the presence of a Scandinavian ice sheet in eastern England
\end{abstract}


at any time during the Quaternary is becoming increasingly doubtful.

\section{Introduction}

Recent glacial models have questioned the timing and dynamic nature of the interaction between the British-Irish Ice Sheet (BIIS) and the Fennoscandian Ice Sheet (FIS) in eastern England. The onshore glacial/interglacial history of the British Isles is complex and fragmentary, and building a coherent chronostratigraphy is challenging. Some models have dated the oldest glacial deposits in East Anglia to MIS 16 (Lee et al., 2004b; Hamblin et al., 2005), while others have suggested the same deposits are MIS 12 in age (Preece et al., 2009; Westaway, 2009b). The provenance of these Norfolk tills has been reported as Scandinavian and British (Perrin et al., 1979; Lunkka, 1994), entirely British (Lee et al., 2002, 2004a), or British with (possibly reworked) Scandinavian erratics (Pawley et al., 2004; Hoare and Connell, 2005).

In northern England, sediments in Yorkshire and Durham have been interpreted as indicating the onshore presence of the FIS in eastern England during MIS 6 (Catt, 1991b, 2001a, 2007). However, the Warren House Formation, at Warren House Gill, County Durham (Fig. 1, Trechmann, 1915, 1931, 1952; Francis, 1972), reportedly contains Scandinavian erratics but pre-dates a raised beach dated to MIS 7 (Davies et al., 2009a), thus questioning that model. As Warren House Gill has previously provided evidence of multiple glaciations, including evidence of a Scandinavian ice sheet, it is a key site to test evolving theories of British and Fennoscandian ice sheet interactions during the Quaternary. The northerly position of the Warren House Formation enables the independent testing of chronological models proposed for Norfolk and Yorkshire (cf. Hamblin et al., 2005). It is therefore important in understanding European Quaternary stratigraphy, as it has the potential to clarify the western extent of the FIS and its interaction with the BIIS during the Middle Pleistocene.

This paper aims to determine the processes of deposition of the glacigenic sediments at Warren House Gill, to determine an event stratigraphy (including provenance and chronostratigraphy), and finally to use this information to create a model of north-eastern England ice sheet history during the Middle Pleistocene. This work therefore tests the hypotheses that the oldest glacial sediments at Warren House Gill represent a subglacial till that is stratigraphically older than the MIS 7 age Easington Raised Beach, and that the till was deposited by a Scandinavian ice sheet. The focus here is on the Warren House Formation (Lithofacies Associations (LFAs) 1 and 2), which includes potentially the earliest Middle Pleistocene glacial deposits in north-eastern England, and which are pivotal in understanding the pre-LGM signal.

\section{Previous research}

\subsection{European Middle Pleistocene glaciations}

There is extensive evidence of large-scale glaciation in Fennoscandia and in the North Sea during each of the main glacial stages (Ehlers et al., 1984; Kleman and Stroeven, 1997; Sejrup et al., 2005, 2009). Coalescence of the FIS and the BIIS in the North Sea Basin has been suggested during the MIS 12, MIS 6 and the MIS 5d to 2 glaciations (Boswell, 1916; Perrin et al., 1979; Catt and Digby, 1988; Bowen, 1999; Catt, 
2001a; Carr et al., 2006), with Scandinavian ice possibly reaching the eastern British landmass during MIS 6 (Catt, 2007) and MIS 12 (Perrin et al., 1979; Bowen et al., 1986; Ehlers and Gibbard, 1991). Others have argued that there is no evidence of the FIS in eastern England during MIS 12 (Lee et al., 2002, 2004a). The Elsterian (MIS 10 or 12) is considered to have been the most significant and extensive glaciation in Germany, where there is evidence of at least two substages, each resulting in a large-scale re-advance (Eissmann, 2002). The age of the tills is constrained by river terrace chronology (Bridgland et al., 2004), and the sediments are overlain by interglacial lake sediments, and then by Saalian (MIS 6) glacial sediments (Eissmann, 2002).

The Anglian glaciation in the North Sea Basin resulted in the deposition of the Swarte Bank Formation, which lies in the base of tunnel valleys, indicating extensive glaciation (Cameron et al., 1992; Laban, 1995; Praeg, 2003; Kristensen et al., 2007). A two-stage glacial signature during MIS 12 in Norfolk has been suggested (Lunkka, 1994; Roberts and Hart, 2005). Evidence for FIS and BIIS coalescence has been suggested in Norfolk in the form of the Briton's Lane Formation, also dated to MIS 12 (Pawley et al., 2004), which contains very rare Scandinavian erratics, and which overlies the Anglian, Scottish-sourced, Lowestoft Formation (Lunkka, 1994; Hamblin et al., 2005). Alternative suggestions include the reworking of older Scandinavian erratics (Pawley et al., 2004). There is also evidence for European glaciation in MIS 8, although it is controversial (see, for reviews, Bridgland et al., 2004; White et al., submitted). The best evidence for MIS 8 glaciation is the type-Saalian of central-eastern Germany, attributed to MIS 8 on the basis of the relation of its outwash with the well-dated terrace sequence of the River Wipper (a Saale tributary) at Bilzingsleben, Thuringia (Mania, 1995; Bridgland et al., 2004). There is also evidence of MIS 8 glaciation in Germany from the sequence in the open-cast lignite mine at Schöningen (Schreve and Bridgland, 2002), although this dating is contradicted by Urban (1995). Nearer to the research area, Beets et al. (2005) and Meijer and Cleveringa (2009) reported an MIS 8 glaciation in the Netherlands sector of the North Sea, based on borehole evidence of till overlain by temperate-stage deposits assigned to MIS 7 from amino acid analysis.

The Bridlington Member (previously the Basement Till) of east Yorkshire is thought to be MIS 6, and reportedly contains rare Scandinavian erratics (Catt and Penny, 1966; Catt, 1991b; Lewis, 1999). The Bridlington Member is overlain by the Sewerby Raised Beach, dated to MIS 5e (Bateman and Catt, 1996; Catt, 2001b), but the age of these glacial deposits remains poorly constrained, as it may overly a shell bed at Speeton (Lamplugh, 1891), dated to either MIS 5e or MIS 7 (Knudsen and Sejrup, 1988; Wilson, 1991). For a more detailed review see Catt (2007).

There is evidence for coalescence of the BIIS and FIS in the central North Sea during MIS 6 in the Cleaver Bank Formation, which occurs beneath the Dogger Bank Formation. This is a partly marine, partly glaciomarine diamicton of eastern provenance, that laterally grades into the subglacial, Saalian, Borkumriff Formation, east of $4 \mathrm{E}$ (Gatliff et al., 1994; Rijsdijk et al., 2005). Langford (2004) suggested that a significant glaciation had reached the English Wash Basin during MIS 10 or 8, and that it might have been related to the same ice advance that deposited the outwash delta at Tottenhill, near Kings Lynn, although these deposits were dated to MIS 6 by Gibbard et al. (1992).Based on evidence from the relation between glacigenic deposits and the palaeo-Trent terraces in the Witham valley downstream of Lincoln, White et al. (submitted) have attributed this glaciation to MIS 8.

The MIS 6 glaciation in the Netherlands and Germany is widely acknowledged to have been particularly 
extensive, with ice sheets extending southwards and eastwards from Norway (Ehlers et al., 1984; Baumann et al., 1995; Eissmann, 2002; Houmark-Nielsen and Gibbard, 2004). A large ice sheet is supported by the presence of tunnel valleys offshore (Huuse and Lykke-Andersen, 2000; Praeg, 2003). In summary, pre-Devensian Scandinavian ice could have reached eastern England in MIS 12, 8 or 6.

\subsection{Warren House Gill, County Durham}

Trechmann (1915) named the basal deposit in the buried palaeovalley at Warren House Gill the 'Scandinavian Drift', and inferred that it was a subglacial till deposited by a Scandinavian ice sheet (Table 1). Boulders of larvikite, rhomb porphyries, nordmarkite and nepheline syenite were reported in situ and on the modern beach by Trechmann (1931). He argued that the deposit was overlain by a reworked loess and that it pre-dated the Easington Raised Beach, at 33 m O.D. in Shippersea Bay (Fig. 1), on the basis that the raised beach contained Norwegian igneous erratics, supposedly derived from the Scandinavian Drift (Woolacott, 1900; Trechmann, 1952). Beaumont (1967) described the basal diamicton at Warren House Gill as a grey, sandy clay with rounded Scandinavian metamorphic erratics, low abundances of Magnesian Limestone (less than 6.5\%), and no Carboniferous Limestone. However, there has been no quantitative heavy-mineral, clast-lithological or palynomorph analysis, which could provide detailed provenance information. Recently, this basal deposit was renamed the Warren House Formation (Table 1, Thomas, 1999).

A recent geochronological analysis (OSL and AAR) found that the Easington Raised Beach was deposited during MIS 7, and that it contains significant percentages of flint and igneous erratics not found in the overlying Devensian tills, and potentially derived from the Warren House Formation (Davies et al., 2009a). Catt (1991a) correlated the Warren House Formation with the Bridlington Member (Basement Till) of East Yorkshire due to the similar ostracod assemblage, and assigned it to MIS 6; therefore, its age and the stratigraphy remain controversial. The Warren House Formation is overlain by the Devensian Blackhall and Horden members (Bridgland and Austin, 1999; Thomas, 1999), equivalent to tills at Whitburn Bay to the north, where they are described in more detail (Davies et al., 2009b). The lithostratigraphy is illustrated in Figs. 2 and 3.

\section{Methods}

\subsection{Lithological analysis}

Stratigraphic analysis followed Jones et al. (1999), Evans and Benn (2004), and Eyles and Lazorek (2007). Sediment characteristics were noted using standard facies codes (Kru“ ger and Kjaer, 1999; Evans and Benn, 2004). Lithological logging, sedimentological descriptions and clast macro-fabrics were conducted according to standard methodologies (Bridgland, 1986, Benn 1994, 2004a, 2004b; Evans and Benn, 2004; Hoey, 2004; Walden, 2004, Benn 2007). Thin sections were prepared and interpreted according to standard procedures (Menzies and Maltman, 1992; van der Meer, 1993; van der Meer, 1997; Menzies, 2000; Carr, 2004; Menzies et al., 2006).

A range of independent, quantified lithological techniques must be applied in order to quantitatively and robustly identify ice accumulation areas, ice flow pathways and lithological correlations (cf. Passchier, 2007). Samples were collected from open field sections, allowing the full variability of the stratigraphy to be 
sampled. The sampling strategy aimed to collect several bulk samples from each facies at each site. Where possible, samples were collected from a vertical profile, demonstrating vertical lithological variation. Where pragmatically possible, a series of vertically spaced samples was collected, to ensure each facies is sampled in a representative fashion (Walden, 2004). Due to the spatial variability of glacigenic diamictons, multiple samples were taken from several vertical profiles to ensure that inter-facies variation is accounted for and that representative samples are taken. Multiple sample collection is important to show replicability and robustness of data, and to determine errors (Hoey, 2004).

We used three principal quantitative techniques to achieve these goals: particle-size, clast-lithological, and heavy-mineral analyses, conducted according to standard methodologies. The sub- $2 \mathrm{~mm}$ fraction was analysed using a Coulter counter. The greater than $2 \mathrm{~mm}$ fraction was determined using wet sieving of large bulk samples (ideally greater than $10 \mathrm{~kg}$ where possible) (cf. Bridgland, 1986; Gale and Hoare, 1991, 1992; Hoey, 2004). Over 300 pebbles greater than $4 \mathrm{~mm}$ and less than $32 \mathrm{~mm}$ diameter were sampled from a $2 \mathrm{~m}^{2}$ area per site to give a statistically significant, representative sample (Bridgland, 1986). Pebbles were carefully washed in water and separated into phi size fractions $(4-8 \mathrm{~mm}, 8-16 \mathrm{~mm}, 16-32 \mathrm{~mm}$, and over 32 $\mathrm{mm}$ ) by sieving. Rock samples were broken open and observed under a standard binocular microscope (model 'Motic SMZ-168'). They were compared to a reference collection collected at outcrop, and standard rock identification criteria (Gale and Hoare, 1991; Walden, 2004). A geological hammer was used to break open the stones to open a fresh surface for identification (Bridgland, 1986). A steel probe was used to test for hardness, and $10 \% 1 \mathrm{M} \mathrm{HCl}$ was used for the identification of carbonates (cf. Bridgland, 1986). However, thin sections were not used to identify the rock samples.

Heavy-minerals were separated using density separation (using sodium polytungstate) and the full-freezing (liquid nitrogen) technique (Davies, in press). Mineral species were identified using a petrological microscope, reference criteria, and photographs (Mange and Maurer, 1992; Mackenzie and Adams, 2001; Walden, 2004). Minerals in the size range 63-250 mm were counted and analysed, as this range allows easier mineral identification.

The data were analysed by multivariate statistical methods to identify trends and correlations objectively (following Davis, 1986; Morton and Hallsworth, 1994, 2007; Kovach, 1995; Ryan et al., 2007; Thamo'-Bozso' and Kova'cs, 2007). Standard descriptive statistics, such as mean and skew, were conducted first, and where applicable, data was square rooted to reduce skew. Multivariate statistical analysis of the heavy-mineral and stone lithology counts allowed simplification of variables in the dataset. Ordination techniques attempt to represent the relationships of the objects of study in a continuum of one or more dimensions. Numerous variables, such as numbers of different heavy-mineral species, give a multidimensional dataset. The main objective of ordination techniques therefore is to reduce the number of dimensions necessary for depicting the major trends in a dataset (Kovach, 1995). Principal Components Analysis (PCA) is an ordination technique that performs linear transformations on multidimensional data to extract axes that summarise as much of the data as possible. It is a method of displaying several correlated variables so that the maximum variation is displayed. This simplifies the numerous variables, highlighting similarities or differences between litho-logical units.

Care must be taken in the analysis of heavy-mineral assemblages, as waterlain sediments may be subject to hydrological sorting of minerals. This can be minimised by using a smaller size fraction. Less dense, platy 
minerals such as micas might remain in suspension longer than denser, cubic or prismatic minerals such as zircon or garnet (Lee, 2003). Processes of deposition may therefore account for some differences in mineral suites (Briggs et al., 1962). Analysis of stable minerals with similar hydraulogical properties can therefore provide additional provenance-specific data (cf. Morton and Hallsworth, 1994, 2007). This study used the minerals zircon, monazite, apatite, and tourmaline. Although apatite can be susceptible to weathering (Morton, 1985), it is relatively stable when compared to the entire mineral suite. The combined use of descriptive statistics, the PCA and cluster analysis, and the use stable heavy-minerals indices, allows a comprehensive comparison of the different lithofacies at Warren House Gill.

\subsection{Chronostratigraphical analysis}

The independent dating techniques used included amino acid racemisation (AAR) of shell fauna and optically stimulated luminescence (OSL). The analysis of intracrystalline proteins were performed according to Penkman et al. (2007a, 2007b, 2008). OSL samples were collected by hammering opaque plastic tubes into sand beds. Sample preparation occurred under subdued light conditions and sand-sized quartz was extracted from the bulk samples using standard laboratory techniques (Aitken, 1985, 1998; Pawley et al., 2008). Heavy-minerals were removed by density separation (using sodium polytungstate) and the remaining grains were etched in $40 \% \mathrm{HF}$ solution for $50 \mathrm{~min}$. Feldspar was dissolved in fluorosilicic acid for 5 days, followed by an $\mathrm{HCl}$ wash for $1 \mathrm{~h}$. External dose rates were calculated from the concentration of radioactive isotopes determined by ICP-MS and in-situ gamma-ray spectrometry. The beta dose attenuation and cosmic ray contributions were accounted for using standard factors (Mejdahl, 1979; Prescott and Hutton, 1994). After drying at $110 \mathrm{C}$ for $24 \mathrm{~h}$, saturated water contents were assessed from the volume/density of the material within the OSL sampling tubes. Water contents were placed at 0.50 .3 of the saturated value and dose rates were corrected for water attenuation (Aitken, 1985). The Single Aliquot Regeneration (SAR) protocol was used to estimate sample De values and all luminescence measurements were performed for 50 $\mathrm{s}$ with the sample held at $130 \mathrm{C}$ to prevent retrapping in the $110 \mathrm{C}$ trap (Murray and Roberts, 1997; Murray and Wintle, 2000).

\section{Sedimentology and stratigraphy}

\subsection{Facies architecture}

Warren House Gill is a contemporary stream valley, incised into older Quaternary deposits that infill a deep, buried palaeovalley (Figs. 2 and 3). The bedrock is a collapse-breccia of Roker Dolomite, a facies of the Permian Magnesian Limestone. The sediments vary laterally across the buried palaeovalley, with a number of different facies exposed in each vertical profile. Following standard hierarchical practise (Evans and Benn, 2004), these facies were grouped into lithofacies (LF) due to similar sedimentological, provenance and genetic properties. Ultimately, these lithofacies were grouped into five lithofacies associations (LFAs; Fig. 3) with similar age, process and provenance characteristics.

LFA 1, the 'Warren House Formation' (as defined by Thomas, 1999), comprises LF 1a (a massive, grey diamicton); LF 1b (stratified diamicton); and LF 1c (deformed association of interbedded grey shelly diamicton and pink silts (LFA 2)), which was observed in Exposure E2. LFA 2, interpreted by Trechmann 
(1952) as loess, overlies bedrock at the southern end of the palaeovalley (see Exposure B, Fig. 3), LFA 1 in the centre (Exposure F and G, Fig. 3), and pinches out to the north (Exposure H). LF 2a comprises well-sorted, laminated and deformed silts. Rounded cobbles occur at the bedrock/LF 2a interface (Exposure B). LF 2b occurs in Exposure D1, and consists of red, interstratified clays, silts and sands, which have been upturned. They are separated from LF $2 \mathrm{a}$ by large clay augen structures. LF $2 \mathrm{c}$ is a deformed diamicton interbedded with LFA 3, seen in Exposure D2 (Fig. 3).

The Devensian sediments comprise LFA 3, the Blackhall Member; LFA 4, the Peterlee Sands and Gravels; and LFA 5, the Horden Member, which all crop out above the Magnesian Limestone cliffs along the Durham coast (Smith and Francis, 1967; Francis, 1972; Bridgland and Austin, 1999; Thomas, 1999). They are not discussed in detail in this paper. LFA 3 unconformably overlies LFAs 1 and 2. It is macroscopically heterogeneous and comprises LF 3a, a dark brown diamicton; LF 3b, gravelly, deformed, bedded sands occurring at around $10 \mathrm{~m}$ O.D. in many exposures; and well-sorted, planar bedded sands (Exposure E1, LF 3c), inter-bedded with LF 3a. LFA 3 is overlain by LFA 4, comprising red, bedded sands and silts (LF 4a) and associated cobble gravel in Exposure K (LF 4b). LFA 5 (the Horden Member) is a massive, stone-rich diamicton, which unconformably overlies LFA 4.

\section{2. $L F 1 a$ and $L F 1 b$ : massive to stratified and deformed diamicton}

At the base of Exposure G (Fig. 4) is a very dark grey, massive, fissile, stone-poor diamicton (LF 1a), containing broken fragments of marine bivalve and gastropod shells. The stone content increases with height in the trial pit. At $2 \mathrm{~m}$ height (13 m O.D.), there is a conformable contact with an overlying diamicton (LF 1b), with a colour change to yellowish brown and then to dark olive brown. The amount of gravel increases and deformed sand laminations appear (Figs. 4 and 5). A clast macro-fabric taken from this location shows little clustering along the a-axis, with a wide range of dip angles. The pebbles are mostly sub-angular in shape, with significant numbers of angular and sub-rounded varieties. Far-travelled lithologies include chalk, flint, red marl, igneous lithics (granite, rhyolite, diorite, porphyry), schist, quartz and orthoquartzite. The clast lithology is dominated by Magnesian Limestone. This facies is overlain by coarse, gravelly sand with an incised, unconformable, convex lower contact (LF 3b), then by the diamicton LF 3a (Fig. 3), with a significantly higher stone content, and finally by red sands at the cliff top (LF 4a).

A micromorphological sample, WHG TS Gi, was taken from LF 1a in Exposure G, at $9 \mathrm{~m}$ O.D. (Fig. 4). Although massive at exposure, the thin section shows a diamicton interbedded with deformed and folded beds of sand with graded contacts (Fig. 6). There are common fine gravel clasts, including soft sediment pebbles, red marl, igneous fragments, quartz grains, shell fragments and marine microfossils. The graded sand beds consist of a moderately to poorly-sorted fine sand matrix, with sub-angular skeleton grains. The microfabric is horizontal in the clay matrix, sub-parallel to the beds. There are planar, bedding-parallel voids and occasional laboratory-induced vugh voids. The graded sedimentary laminations show soft sediment deformation. Dropstones deforming underlying laminations and with overlying draped bedding are clearly apparent (Fig. 7A and C). The bedding has subsequently been boudinaged and is cross-cut by clay-lined microfaults (Fig. 7C). There is a well-developed masepic plasmic fabric (Fig. 7A-C) and some manganese oxide staining. Within the diamicton, there are lineations of grains with associated plasmic fabric development, rare rotations (Fig. 7A), a rotated intraclast with a tail (Fig. 7D and E). Fig. 7F shows a 
lamination which has been faulted downwards. The association with a grain lineation demonstrates the effects of shear.

Thin section WHG TS Gii was sampled from LF $1 \mathrm{~b}$ at Exposure $\mathrm{G}$ at $11 \mathrm{~m}$ O.D. (Table 2). It is a dark olive brown, iron-stained diamicton with large vugh voids. It is mostly fine-grained with one large irregular schistose skeleton grain. There is poor impregnation in one part of the slide. Texturally, the diamicton is a fine sand or silt with some fine material. The skeleton grains are sub-rounded to sub-angular, with numerous angular fine skeleton grains, predominantly composed of quartz and plagioclase feldspar, red marl, sandstone, basalt, and other igneous fragments. Soft sediment intraclasts are present. There are rare microfossils, including ostracoda and foraminifera (Table 2), and shell fragments. Structural analysis reveals banded matrix material, associated with masepic plasmic fabrics. There are abundant grain lineations associated with rotational structures, both with and without a core stone, again associated with masepic plasmic fabrics. There are lineations of grains, with aligned long axes.

In Exposure F (NZ 44713 42320), two diamictons are superposed (Fig. 3). The basal diamicton, LF 1b, is a stone-poor, dark grey, fissile diamicton with sheared and deformed laminations and broken marine bivalves. A bed of coarse, poorly-sorted, bedded sand with a scoured, convex basal contact (LF 3b), overlies LF 1b, and is in turn overlain by LF $3 a$.

WHG TS F was taken from LF 1b, Exposure F, at $13 \mathrm{~m}$ O.D. Macroscopically, the sample is a massive, dense, brown, matrix-supported diamicton (Table 2). There are occasional red marl grains, fine gravel grains, marine microfossils and shell fragments. The sub-angular to sub-rounded skeleton grains are poorly sorted, but are mostly less than $100 \mathrm{~mm}$. There is some highly deformed graded bedding within the diamicton. Structural analysis reveals stratification, occasional rotational structures with associated necking structures, soft sediment pebbles with their own internal plasmic fabric, multiple clay domains, and rare grain lineations. There are rare crushed grains with fragments separated by plasma. The matrix is banded, and the plasmic fabric reveals a moderately developed skelsepic and cross-cutting varieties of masepic plasmic fabric.

\subsection{LF 1c: deformed diamicton}

Exposure E2 (Fig. 8), on the southern side of the current stream, exposes the contact between LFAs 1 and 2. This is the northern limit of LFA 2. Here, LF $1 \mathrm{c}$ is a stone-poor grey diamicton bearing fragments of bivalve shells, chalk and flint gravel, and red marl pebbles. Folded into this diamicton are narrow laminae of yellowish-brown silt (LFA 2), which are extended, faulted, folded and deformed, with stringers extending from the silt into the diamicton. Coarse sands and gravels (LF 3b) overlie LF 1c, and are in turn overlain by diamicton (LF 3a), within which is a large pod of crudely bedded, overturned, gravelly sand (LF 3b).

\subsection{LF 2a: massive to laminated silts}

LF 2a in Exposure B shows $1.3 \mathrm{~m}$ of stratified, deformed silts on bedrock (Figs. 9 and 10), overlain by a stratified diamicton (LF 3a). LF 2a is yellowish-brown sandy silt with deformed, folded silt and clay stratified beds (Fig. 9A). Black beds are interbedded within the silts (Fig. 9B), but they contain no pollen or other discernible organics, and may well be manganese. The bottom contact is complex, undulating and uneven. The soft Magnesian Limestone bedrock is brecciated, the limestone set in a silt matrix (Fig. 9C). Stringers of limestone also extend upwards into the silts. At the bedrock interface, there are several well-rounded exotic 
cobbles, including Carboniferous Limestone and sandstones (Fig. 10). Towards the top of LF 2a in Exposure B, the sediment is increasingly stratified. There are discontinuous planar beds of gritty sand interbedded within the silts, which pinch and swell. These grade into a $10 \mathrm{~cm}$ shear zone below LF 3a, which pinches out towards the northern end of the section (Fig. 10).

LF 2a in Exposure C (Fig. 3) rests on a grey diamicton bearing shell fragments (LFA 1) on bedrock (observed in a borehole). Above this is over $5 \mathrm{~m}$ of a fine-grained, well-sorted silt, mostly massive with some fluidised sand and clay laminations, overlain by a stone-rich brown diamicton (LF 3a). Within LF $2 a$, flecks of coal and rounded cobble-sized calcium carbonate concretions (race nodules) are present in situ. The deformation increases upwards towards LF 3a, with strongly fluidised sand and clay beds with numerous rounded clay intraclasts towards the top. Water escape, pipe, ball and pillow, and flame structures are abundant in LF 2a. The contact with the diamicton above is sharp and sheared.

Exposure D1 is in the deepest part of the palaeovalley (Fig. 3). Excavations revealed over $5 \mathrm{~m}$ of LF 2a, and did not reach the contact with either bedrock or LFA 1 (Figs. 11 and 12). At the base of the trial pit, LF 2a is exposed, with well-sorted silty sands showing fluidisation and disturbed laminations, including tightly overturned folds (Fig. 12). The intensity of deformation increases upwards. Micromorphological sample WHG TS Di was taken from LF 2a at $1.3 \mathrm{~m}$ height (Fig. 13 and Table 2). The silt is well-sorted with occasional deformed clay laminations. On macroscopic inspection, it has a variable texture showing extensive deformation of primary fluvial bedding structures. The skeleton grains mostly consist of well-sorted silt, predominantly quartz, and are angular to well-rounded in shape. Rare larger sand grains are sub-angular to sub-rounded in shape. The thin section has two large vugh (laboratory-induced) voids, which may be related to manganese staining of the sediments (Fig. 13A). Skeleton grains are typically aligned north-south. Structural analysis reveals graded bedding structures including the foresets of a climbing ripple. This conformable, graded bedding has been extensively fluidised under saturated, loaded conditions (cf. Phillips et al., 2007). Cutting through the deformed bedding are a series of faults (Fig. 13A). A sheared and attenuated clay intraclast is associated with lineations of micro-fabric and small skeleton grains. This deformation is emphasised by the clear lattisepic and masepic plasmic fabric.

\subsection{LF 2b: upturned, interbedded sand and clay}

In Exposure D1, LF 2a is capped by a bed of clay that dips downwards to the north. It swells sharply into two distinct clay pods (augens) with internal sub-vertical, deformed laminations (Figs. 11 and 12). The sediment above the clay augens (LF 2b) in Exposure D1 is significantly different from that below, consisting of incoherent, interbedded sand and clay with a distinct sub-vertical nature (Fig. 11C). These complex interstratified sediments are heavily deformed and contain rare shell fragments. Towards the contact with the overlying diamicton, the sedimentary beds become increasingly sub-horizontal to horizontal, resulting in more coherent laminations (Fig. 11B). This is overlain by a narrow, discontinuous bed of poorly-sorted gritty sand with some internal stratification, which grades into a $10 \mathrm{~cm}$ thick bed of clay. There is evidence of incorporation of the sediments below in the form of soft sediment pebbles, and the clay extends in places as stringers into the diamicton above. The clay bed contains rare pebbles similar to those in the diamicton above. The upper contact is sharp and undulatory (Fig. 11B).

WHG TS Dii was sampled from LF 2b, Exposure D1, from the heterogeneous sediment above the clay augen structures (Figs. 11 and 13B). The sand shows deformation structures, and the clay laminations are 
deformed and disjointed. The slide constitutes mostly well-sorted silt with some sand grains. There are also soft sediment pebbles visible, with coherent internal plasmic fabric (van der Meer, 1997). Iron staining along grain boundaries is apparent. Thin-section study indicates that the silt grains are predominantly angular to sub-angular in shape, while the larger sand grains are more rounded (Table 2). The matrix is composed of silt skeleton grains with some clay. The voids are vugh-type, with some bedding-parallel voids, probably caused during packing. The laminations indicate primary deposition in water, followed by strong deformation. There has been 'flow' of the bedding (Menzies et al., 2006). This deformation is related to the development of a common latti/skelsepic plasmic fabric within the clay matrix.

WHG TS Diii was taken from the contact between LF 2b and LF 3a, Exposure D1 (Fig. 11 and Table 2). It is a macroscopically homogeneous, moderately well-sorted, massive silt with numerous large round clay intraclasts, sometimes with their own plasmic fabric. Angular to sub-angular silt skeleton grains are evenly distributed across the slide. There are some indications of crude primary bedding. The matrix displays a weakly developed latti/ skelsepic plasmic fabric.

\section{6. $L F 2$ : deformed and interbedded diamicton}

The contact between LFA 2 and LFA 3 is poorly exposed but is visible in Exposure D2 (Fig. 13), where they are complexly inter-bedded. LF $2 \mathrm{a}$ is well exposed in the base of the trial pit, and is overlain sharply and unconformably by a dark brown diamicton (LF 3a). The silts show evidence of shear, loading and soft sediment deformation. Above this, the diamicton is interbedded and mixed with coarse, poorly-sorted sands (LF 3b; Fig. 13).

WHG TS D2 was taken from LF 2c, the interbedded, tectonised layer between LFA 3 and LFA 2 in Exposure D2 (Fig. 14). It captures the contact between the beds of LFA 2 and LFA 3. Bright red sand stringers dissect the brown, poorly-sorted diamicton (Fig. 15). Within the diamicton, larger fine gravel skeleton grains are sub-rounded and irregularly dispersed, and the matrix is unevenly distributed across the slide. Skeleton grains include limestone, sandstone, quartz, feldspar, basalt, shell fragments, and soft sediment pebbles. The contact between the sand stringers and diamicton varies between sharp and diffuse. The diamicton beds are characterised by boudinaged and banded matrix material, displaying unistrial plasmic fabrics, grain lineations and turbate structures, including rotated, augen-shaped intraclasts, necking structures with plasma squeezed between skeleton grains, pressure shadows and some limited skelsepic plasmic fabric.

\section{Lithology, petrology, biostratigraphy and chronostratigraphy}

\subsection{Sediment description and grain size analysis}

LFA 1 grades from a dark grey (10YR 4/1) clay with rare gravel to a dark olive brown (2.5YR 3/3) diamicton with increasing stone content and tectonised sand laminations. Fig. 16A shows the separate particle-size envelopes LFA 1, 2 and the other lithofacies associations at Warren House Gill. LF 1a has a bi-modal particle-size distribution, peaking in fines and in gravel (Table 3). The amount of coarse sand and gravel increases in LF 1b (Table 4; Fig. 16B). Sedimentological analysis clearly shows the increase in sand and pebbles in LF 1b. However, this fine-grained diamicton has very little coarse sand and gravel compared to LFAs 3 and 5. The LF 3a diamicton samples WHG G4 and F3 are presented for comparison and obviously have 
far more gravel and substantially less sand. LFA 2 is a yellowish-brown (10YR 5/6) well-sorted silt (Fig. 15A) with a vigorous reaction to $\mathrm{HCl}$.

\subsection{Heavy-mineral analysis}

LFA 1 has lower percentages of opaque minerals (39\%) and non-opaques such as zircon (3\%), kyanite $(2 \%)$, apatite $(2 \%)$, and relatively high proportions of garnet (17\%), actinolite (9\%), epidote (8\%), hornblende (4\%), hypersthene (4\%), and monazite (6\%), when compared to LFAs 3, 4 and 5 (Table 5). The presence of rare minerals such as pumpellyite and piedmontite is unusual in eastern British glacigenic deposits. The heavy-mineral suite of LFA 2 closely reflects that of LFA 1 (Table 5). To explore and to simplify the heavy-mineral dataset, the mineral species were divided into six groups: phyllosilicates, metasedimentary and detrital epidotes, pyroxenes, amphiboles, carbonates and phosphates. A correlation matrix showed that carbonates, amphiboles, pyroxenes and phosphates are related and explain much of the variance in the dataset. In a ternary diagram of the relative proportions of these groups of minerals, LFA 1 forms a tightly clustered group, with high proportions of amphiboles and pyroxenes, but with low proportions of phosphates. LFA 2 plots very close to LFA 1, but is differentiated by high percentages of pyroxene (Fig. 17A). The apatite-monazite and apatite-tourmaline indices, which are independent of settling velocities or instability, also clearly demonstrate the uniqueness of LFA 1 (Fig. 17B). Sample WHG F3 consistently plots close to LFA 1. This sample was taken close to the contact between the lithofacies, and may therefore contain minerals derived from the lower facies.

In a PCA covariance, the first two components explain $66 \%$ of the total variance, and their plot is therefore an accurate representation of the whole dataset (Fig. 17C). The sediments of LFA 1 and LFA 2 plot in a well-defined envelope, due to their comparatively high proportion of amphiboles. One LFA 3 sample (WHG F3) plots within the LFA 1 envelopes in Fig. 17B and C. In a cluster analysis performed in parallel to the PCA (Fig. 17D), LFA 1 again forms a tight, well-defined cluster, illustrating its uniqueness at Warren House Gill. However, the cluster dendrogram and PCA do not discriminate between the other lithofacies, which are well scattered.

\subsection{Clast-lithological analysis}

The pebble lithologies of LF $1 \mathrm{~b}$ differ profoundly from those of LF 3a, LF $4 \mathrm{~b}$ and LFA 5 (Table 6). LF $1 \mathrm{~b}$ is significantly lower in Magnesian Limestone (53\%) and Carboniferous Limestone (3\%), but is comparatively enriched in igneous, metamorphic, Cretaceous and Triassic pebbles. LF $1 \mathrm{~b}$ has few locally derived lithologies but a strong component of far-travelled igneous erratics. There is a relatively high percentage of granite (3.7\%), andesite (2.1\%) and vein quartz.

In the PCA (Fig. 18A), the first two components account for $68 \%$ of the variation in the dataset, and are acceptably the best representation of the variation. Component 1 (52\% of the variation) is determined principally by Cretaceous and quartzose lithologies on the positive axis, and Southern Uplands material (Carboniferous sandstones and limestones, Old Red Sandstone, quartzite, greywacke) on the negative axis. Component 2 is mainly determined by Permian and Jurassic lithologies, and accounts for $16 \%$ of the variation. The third component accounts for $11 \%$ of the dataset, and is mostly related to the amount of sandstone. The PCA clearly distinguishes three groups: the Easington Raised Beach, LFA 1 and the three other lithofacies, predominantly differentiated by the presence of Cretaceous, igneous and quartzose 
lithologies. The raised beach is principally separated as it contains only highly durable and largely local lithologies, less durable lithologies being rapidly eradicated in the high-energy beach environment. Cluster analysis also differentiated between LFA 1 and the raised beach gravel, but failed to distinguish between LFAs 3, 4 and 5 (Fig. 18B).

\subsection{Palaeontological results}

LFA 1 yielded Chlamys sp., Hiatella sp., and Balanus sp. bivalve fragments, which were too broken to and poorly preserved to identify beyond species level. Samples WHG F1 (89 specimens counted) and WHG G2 (221 specimens counted), both from LFA 1, contained well preserved benthic arctic foraminifera species (Fig. 19), with high percentages of Elphidium excavatum f. clavata. Subsidiary species include Cassidulina reneforme, Cibicides lobatus, Haynesina germanica, and planktonic forms. Unidentified forms accounted for $12 \%$. These species are typical of cold, turbid, open-marine environments.

Sample WHG C2 from LF 2a yielded small foraminifera (82 well-preserved calcareous benthic arctic foraminifera species specimens counted), which consisted primarily of unidentified planktonics and the benthic calcareous species Elphidium sp., Haynesina germanica and Brizalina variabilis. There are very rare examples of $C$. lobatulus and Cassidulina sp. Some of these species suggest similar environmental conditions to those in LFA 1 , but others ( $\mathrm{H}$. germanica and $\mathrm{B}$. variabilis) are characteristic of temperate inter-tidal environments. The LFA 2 fauna are in good condition and show little sign of reworking.

Sample WHG F1 (LF 1b) was analysed for palynomorphs and kerogen (Riding, 2007; Table 7). Wood fragments are common. Carboniferous spores in WHG F1 (2.3\%) are rare when compared to LF 3a (c. 99\%), and are largely Densosporites spp. and Lycospora pusilla. Jurassic palynomorphs (0.1\%) and the characteristic Early Cretaceous genera Cicatricosisporites spp. (spore) and Cribroperidinium (dinoflagellate cyst) were observed in low numbers (0.3\%). Significant numbers of Eocene dinoflagellate cysts are present, including Areosphaeridium diktyoplokum (Ypresian-Priabonian), Deflandrea oebisfeldensis (Late Palaeocene-Early Eocene), Eatonicysta ursulae (Ypresian-Lutetian), undifferentiated chorate (process-bearing) forms, and Homotryblium spp. (ages defined by Powell, 1992). Large amounts of typical Quaternary pollen and spores, including Alnus, Corylus, Filicales, Pinus, Sphagnum-type, and The extent of protein diagenesis was measured within the Tilia, are also present in LF 1b (Riding, 2007).

\subsection{Chronostratigraphy}

The extent of protein diagenesis was measured within the intracrystalline fraction, isolated, for the first time, from bivalve fragments tentatively identified as Hiatella from LFA 1 . This genus has been analysed previously for AAR of the whole shell (Goodfriend et al., 1996; Manley et al., 2000) but, as the intra-crystalline protein fraction is different, the results are not as yet comparable (Penkman et al., 2008). The intracrystalline proteins of some mollusc shells have been shown to behave as a closed system during diagenesis and can therefore provide more reliable age determination than the total shell protein (Penkman et al., 2008). In LF 1a, the shells may not be in situ, but could have been derived from earlier deposits. As 
such, shells of a range of ages may be incorporated; the age of the youngest shell defines the maximum age of the sediment (Bowen et al., 2002).

L-and D-enantiomer pairs of multiple amino acids were separated on an automated RP-HPLC system, using a modified method of Kaufman and Manley (1998). Both the Total Hydrolysable Amino Acids (THAA) and the Free Amino Acid (FAA) fractions were analysed. Within a closed system, these two parameters display a high degree of correlation (Penkman et al., 2008). The limited data from Hiatella displayed this closed system behaviour for all the eight samples considered in this study (NEaar 4688-4895). Each sample was analysed in duplicate (Fig. 20 and Table 8).

However, different molluscan genera are characterised by different amino acid signatures, even within the closed system (the "species effect") (Penkman et al., 2007b, 2008). As a consequence, independently calibrated chronological frameworks have to be developed for each genus. Unfortunately such a database has yet to be developed for Hiatella and an absolute age for WHG F1 (LFA 1) could not be obtained at this stage.

The degradation patterns in Hiatella were compared with available data from the terrestrial genus Bithynia, for which a calibrated framework has been established (Penkman et al., 2007b). Multiple amino acids were considered as diagenesis indicators, in order to obtain independent validation of the data (Penkman et al., 2008). Note that during preparative hydrolysis, both Asparagine (Asn) and Glutamine (GIn) undergo rapid irreversible deamination to aspartic acid (Asp) and glutamic acid (Glu) respectively. It is therefore not possible to distinguish between the acidic amino acids (Asp and Glu) and their derivatives (Asn and $G(n)$, and they are reported together as Asx and Glx.

The amino acid Asx and Glx yielded results which were comparable with the reference genus, with $D / L$ values, measured on both the total hydrolysable amino acid (THAA) and the free amino acid (FAA) fractions, consistent with the ratios obtained for terrestrial shells with an age of MIS 9 - MIS 11 (Fig. 20). On the contrary, Alanine (Ala) and Valine (Val) displayed a much higher extent of degradation, with D/L values which would indicate an age older than the Cromerian for the terrestrial reference genus (Fig. 20). This indicates that diagenesis follows different pathways in Hiatella and the terrestrial shells. As a consequence, the two datasets cannot be compared in order to obtain age information and AAR alone cannot yield conclusive age estimates at this stage. However, this will become possible as more, independently calibrated, Hiatella samples are analysed and the diagenesis patterns investigated in more detail. The extent of AAR suggests only a Middle Pleistocene or older age for LFA 1.

Samples were collected from LFA 2 and LFA 3 for OSL dating and their suitability for the SAR protocol was assessed from the characteristics of the luminescence signal, pre-heat De dependence, and dose recovery tests. The samples collected from LFA 2 proved to be unsuitable for dating as their natural OSL signals were found to be very close to saturation ( $>500 \mathrm{~Gy}$ ) and the samples failed to recover a known laboratory dose of $400 \mathrm{~Gy}$ administered after a $1 \mathrm{ks}$ bleach, overestimating it by 1.420 .26 . In contrast, three samples taken from the fold nose in Exposure E1 (LF 3c, Fig. 3) showed good dose recovery values (1.01 0.03) and no dependence of De on preheating conditions between 160 and $260 \mathrm{C}$. However, the samples produced ages that are highly scattered between 82 and 124 ka (Table 9) and it is possible that complete resetting of the OSL signal did not occur. Unfortunately, the intensity of the OSL emissions in these samples was also relatively low which precludes making single-grain measurements to test for mixed-grain populations. The 
dates are therefore considered to represent maximum ages with LFA 3 mostly likely dating to the Early Devensian or younger.

\section{Interpretation and discussion}

\subsection{Processes of deposition}

The basal facies at Warren House Gill, LF 1a, has the macroscale and microscale hallmarks of a glacially-influenced waterlain deposit subsequently subjected to glaciotectonism. The evidence includes graded Type 2 laminations (cf. Roberts and Hart, 2005), far-travelled lithics, conformable contacts, dropstones, weak plasmic fabrics, turbid water foraminifera, fossil shell fragments, and stratification (cf. Boulton and Deynoux, 1981; Domack, 1984; Powell, 1984; Eyles et al., 1985; Hart and Roberts, 1994; Merritt et al., 1995; Carr, 2001; O Cofaigh and Dowdeswell, 2001). The microscopic deformed graded bedding, dropstones, stratification and the lack of plasmic fabric development also indicate that this is a glaciomarine diamicton, deposited by mass flow and rainout from a glacier terminus. The boudinage, rotation, deformed beds, faulting and folding in LFA 1 (Table 2) suggest that it was subjected to post-depositional soft sediment deformation and glaciotectonism (Powell, 1984; Eyles et al., 1985; Powell and Molnia, 1989; Hart and Roberts, 1994; Carr, 2001; Hiemstra, 2001).

The foraminifera E. excavatum forma clavata and C. reneforme are typically found in turbid arctic environments and are associated with glaciomarine conditions (Hald and Korsun, 1997). C. lobatulus is usually found more distal to the ice margin. H. germanica lives in open-water conditions (Hald and Korsun, 1997; Jennings et al., 2004). The variety of species with the dominance of $E$. excavatum suggests that the sediment was deposited in cold marine water some distance from the ice margin. The well-preserved nature of the foraminifera tests suggests limited reworking. It is noteworthy that glaciomarine rainout diamictons typically have paired in-situ marine bivalves (Eyles et al., 1989). However, no in situ paired bivalves were observed in LF1. Combined with the evidence for waterlain sedimentation, the broken fragments imply that the shells have been reworked, and may be derived from pre-existing sediments.

LF 1a grades into the more proximal LF 1b (reflected by upwards coarsening; Fig. 16B), dominated by suspension settling with increasing inputs of ice-rafted debris as the ice front advances. The deformed graded laminations in LF $1 \mathrm{~b}$ are related to remobilisation and subsequent resettling of material by subaqueous traction currents, which are typical processes in glaciomarine environments (cf. Eyles and Eyles, 1983). They were subsequently glaciotectonised, as shown by the faulting, shearing and folding observed in the thin sections. The clast macro-fabric from LF $1 b$ (Exposure G, Fig. 4) shows very little clustering along the a-axis and a high but variable dip angle, which is typical of glaciomarine diamictons (Powell, 1984; Domack and Lawson, 1985; Powell and Molnia, 1989; McCabe et al., 1993; Hart and Roberts, 1994). LFA 1 is therefore interpreted as being deposited by the rapid rainout of material from dense sediment-laden underflows (cf. Lee and Phillips, 2008); the coarsening upwards particle-size distribution (Fig. 15) being related to the increasing proximity to the glacier terminus.

Increased shear and deformation is apparent in LF $1 \mathrm{~b}$, and the sediment is increasingly homogenised. WHG TS F exhibits deformed primary depositional features such as graded bedding. The lack of strong turbates, grain lineations, and a strong plasmic fabric, despite the high clay content, indicates a low stress 
signal and unlikely derivation as a subglacial till (Carr, 2001; Khatawa and Tulaczyk, 2001). Deformation was induced post-depositionally by ice push, dewatering, and increase in ice-overburden pressure, resulting in ductile deformation, fluidisation of laminations, grain rotation and shear (Phillips et al., 2002). Brittle faulting cutting across the fluidised soft-sediment deformation occurred during the final phase of glaciotectonic deformation, probably induced by lowered porewater pressure (Hart et al., 2004; Phillips et al., 2007). The increasing deformation signal with height in the sediment pile is therefore related to increasing secondary glaciotectonism induced during glacier override.

The pink silts in LF 2a contain microfossils, graded bedding and Type A climbing ripples (as defined by Allen, 1963), signifying that LF $2 a$ was deposited in a shallow subaqueous environment (see Fig. 13). The heterogeneity of grain size suggests that it could be reworked loess, as originally defined by Trechmann (1952). The foraminifera assemblage is distinct from that of the underlying LFA 1(Fig. 19) and suggests a temperate, shallow, inter-tidal to estuarine zone (cf. Horton and Edwards, 2006). Thin-section samples WHG TS Di and Dii from Exposure D1, LF 2a, show abundant evidence of soft-sediment deformation (Fig. 13). Liquefaction and fluidisation are related to vertical loading, in this case either the weight of ongoing sedimentation or loading by ice-overburden pressure (Mills, 1983; Phillips et al., 2002, 2007). As porewater pressure decreased the sediments were faulted and fractured through brittle deformation (Hart et al., 2004).

The clay augen structures in Exposure D (Fig. 11) are 'clast and tail' features, with the narrow clay beds extending out to form the augens' 'tails'. The non-graded clay laminations, the rotated, augen-shaped clay clasts, and the lack of lateral continuity of the clay laminations are similar to structures observed in Norfolk and elsewhere (e.g., McCarroll and Harris, 1992; Roberts and Hart, 2005; Hart, 2007; Ó Cofaigh et al., 2008), where they are indicative of compression, longitudinal extension and rotational shear through subglacial deformation (Hart and Boulton, 1991; Piotrowski and Kraus, 1997; Hart, 2007). The augen structures are overlain by LF $2 \mathrm{~b}$, where evidence of loading, soft-sediment deformation, fluidisation and dewatering (as defined by 1983) are apparent. The upward-turned fan shapes of these sediments are characteristic of water escape induced by loading (potentially ice-overburden pressure related to the emplacement of LFA 3 above). Micromorphological analysis of the contact between LF $2 \mathrm{~b}$ and LF 3a (WHG TS Diii) shows that the homogenised silt with clay and silt intraclasts has been subjected to shear stress, resulting in the minor plasmic fabric development, hindered by a lack of fines.

In Exposure E2, LF 1C clearly shows mixing between LFA 1 and 2, with rooted structures, stringers extending southwards, attenuated folds, deformed inclusions, and boudinage (Fig. 8). These penetrative structures are typical of subglacial glaciotectonic deformation (cf. Evans et al., 1995; Roberts and Hart, 2005; Hart, 2007; Lee and Phillips, 2008; Phillips et al., 2008), and typically occur beneath grounded subglacial ice at the shear zone (van der Wateren, 1995; Benn and Evans, 1996). The sandier facies of LFA 2 would have resulted in a decrease in shear strength through a comparative increase in porewater content (Evans et al., 2006), and deformation could therefore occur even at low shear strains (as discussed by van der Wateren et al., 2000). The lack of lateral continuation of this glaciotectonite highlights the intensely localised ductile deformation. This deformation probably occurred during emplacement of LFA 3 above.

Additional evidence of glaciotectonic deformation is also visible in LF 2c, in Exposure D2 (Figs. 13 and 14). Structures typical of subglacial deformation include stringer initiation (Roberts and Hart, 2005), attenuation of folds (Lee and Phillips, 2008), deformed inclusions and intraclasts (Berthelsen, 1979; Evans et al., 1995; 
Hicock and Fuller, 1995), and mixing in the lower parts of the till with rooted structures, shear lenses, till wedges and attenuated folds (van der Wateren, 1995; Hart, 2007). The thin section of the contact (WHG TS D2) shows stringer initiation into LF $3 a$, due to subglacial ductile deformation under water-saturated conditions. The sharp contacts of the ungraded red sand beds confirm that these are the initiation point of Type 1 laminations (cf. Roberts and Hart, 2005). This glaciotectonite was therefore formed through low-strain subglacial shearing (van der Wateren, 1995; Phillips et al., 2002; Hiemstra et al., 2007).

\subsection{Event stratigraphy at Warren House Gill}

LFA 1 and LFA 2 therefore include a variety of facies, from those exhibiting minimal soft sediment deformation and fluidisation (LF $1 a$ and LF $2 a$ ) to those with extensive evidence for glaciotectonic processes (LF 1C and LF 2C). A five-phase event stratigraphy can be identified (Fig. 19). In Phase 1, LFA 1 was deposited as a glaciomarine rainout diamicton and experienced syn-depositional soft-sediment deformation. During Phase 2, LFA 1 was overridden by the ice mass that deposited it and underwent extensive glaciotectonic deformation (Fig. 19B), as observed in Exposure G (Fig. 5). Increasing deformation is apparent higher in the sediment pile, explained by the decreasing transmission of stress downwards (van der Wateren, 1995; Phillips et al., 2002)(Fig. 21A). This was followed by the recession of the ice sheets and the conformable deposition of LFA 2 (Phase 3, Fig. 21B).

In Phase 4, LFA 2 was liquefied, fluidised, sheared and tectonised during the emplacement of LFA 3 above (Fig. 21A). In Exposure D1 (Fig. 11), water escape, fluidisation and shear stress resulted in the formation of LF $2 \mathrm{~b}$, the augen structures, and the shear zone contact with LFA 3 (Fig. 11B). In Exposure B, shear stress was transmitted to bedrock, as can be seen by the brecciation of the Magnesian Limestone (Figs. 9 and 10). The amount of deformation increases in a continuum to Phase 5, where penetrative deformation in a thin sediment pile tectonised LFA 1 with LFA 2 (to form LF 1c, Fig. 8). Where the pile was thicker, as in Exposure D2, LFA 2 and LFA 3 were tectonised together, and LFA 1 was left undisturbed. In Exposure D1, with a much greater thickness of LFA 2, sediments near the base were subjected to only minor disturbance (LF 2a), whereas sediments higher up in the pile experienced shearing, dewatering, and glaciotectonism (LF 2b), due to the increase in penetrative stress upwards through the sediment pile towards the ice/bed interface (cf. Evans et al., 2006).

\subsection{Chronostratigraphy}

LFA 2 has an open-marine, temperate fauna, suggesting deposition during an interglacial period. It is overlain by an Early Devensian till (Table 9), indicating that LFA 2 is at least MIS 5 e or older. This provides an upper age limit on LFA 1 of MIS 6. LFA 1 contains a Middle Pleistocene shell fauna, dated by amino acid racemisation.

Lithological analysis of the nearby Easington Raised Beach (Fig. 1) clearly indicates crystalline and Cretaceous elements present within both the raised beach and LFA 1 (Fig. 16). These components are not present in the Devensian sediments in the vicinity (Table 6). The only current known and thus the most likely source of the rare Cretaceous and quartzose erratics within the raised beach is LFA 1 (cf. Davies et al., 2009a). The Easington Raised Beach has been well constrained by OSL and AAR to MIS 7 (Bowen et al., 1991; Davies et al., 2009a), which dates LFA 1 to older than MIS 7. It is not possible for the raised beach to have 
been deposited first and then to have been reworked, providing the far-travelled erratic component to LFA 1. The raised beach, being a high-energy environment, contains only durable lithologies, whilst LFA 1 contains a number of soft, non-durable lithologies such as granite, red marl, chalk, schist and slate (Table 6), which are not present either in the Easington Raised Beach or in the younger glacial sediments at Warren House Gill.

If there was an earlier, separate glaciation, bringing Cretaceous rocks from the North Sea floor and igneous erratics from Scotland/ Scandinavia, the resulting glacial deposit could be the source for the erratics in the Easington Raised Beach, and the raised beach could therefore be irrelevant to the age of LFA 1 . However, this is unlikely as there is no evidence for such a glaciation on the coast of northern England. The most probable solution is that LFA 1 was the source of the far-travelled erratics within the raised beach.

Therefore, the simplest explanation is that the erratics within the raised beach were derived from LFA 1, which is currently the only existing source of eastern-provenance lithologies, and that LFA 1 therefore pre-dates the Easington Raised Beach. Combined with the amino acid evidence, this strongly suggests an age range of MIS 8 or older for LFA 1. This is discussed in more detail in Davies et al. (2009a). An MIS 8 age is possibly more likely than MIS 10 or 12 , as if it was deposited in the base of a palaeovalley during MIS 12 , this palaeovalley would have had to have been impossibly deep, due to a long and sustained period of tectonic uplift since the Cenozoic (refer to uplift discussion below and to Westaway, 2009a), although this is speculative. In addition, note new and emerging evidence from the Trent valley and Tottenhill, which indicates clearly that there was a large post-Anglian, pre-Devensian glaciation of eastern England to the south of County Durham (Gibbard et al., 1992; Langford and Briant, 2004; Carney, 2007). Due to the lack of directly dateable material, the chronostratigraphy at this time remains uncertain and LFA 1 probably dates to between MIS 12 and 8, and it is highly likely to be older than MIS 6, as stated by previous workers.

\subsection{Provenance}

Eocene marine palynomorphs are rare in tills from eastern England (Lee et al., 2002; Riding et al., 2003), so the Eocene dinoflagellate cysts in LFA 1 are highly significant. There are no onshore outcrops of Eocene rocks in the Durham area or to the north. Hence, these must have been derived from the North Sea Basin to the north or northeast, where post-Cretaceous sedimentary rocks are present at, or close to, the sea bed. By contrast, the dominance of Carboniferous spores in LF 3a suggests that the majority of the material was derived locally from the Northumberland and Durham coalfield.

LFA 1 contains Late Cretaceous chalk, flint, and microfossils from the north-eastern North Sea, and the Triassic Red Marl, which outcrops in the near offshore region, and rarely in fissures in the limestone bedrock onshore. The gravel lithology of LFA 1 includes Magnesian Limestone and a significant number of metamorphic quartzose lithologies. There is relatively little local or Pennine input, reflected in the low proportions of Carboniferous Limestone, sandstone, coal, and shale (Table 6). No rhomb porphyries or larvikites from southern Norway were found, though these have previously been reported (Trechmann, 1915, 1931). A single large boulder of alkali K-feldspar granite with quartz, plagioclase, minor biotite and no muscovite was recovered from LFA 1. Alkali-feldspar granites do not occur widely in north-eastern Scotland, and this source is excluded by the absence of muscovite (cf. Stephenson and Gould, 1995). A possible source for this granite is the Permian Drammensgranit from the Oslofjord region of Norway (cf. Oftedahl, 1960; 
Smed and Ehlers, 1994).

Various other lithologies within LFA 1 are probably derived from Scotland or northern England. These include Cheviot andesite, which crops out in north-eastern England, and a typical Aberdeenshire alkali K-feldspar granite with muscovite and hornblende (Stephenson and Gould, 1995). Several syenites were found; these are variable and wide-ranging, and could be derived from either Norway, the Scottish Basement or the Grampian Highlands (Oftedahl, 1960; Smed and Ehlers, 1994; Stephenson and Gould, 1995). WHG C1 includes a single low-grade mafic-rich metamorphic erratic, typical of those from Aberdeenshire.

The metamorphic mineral assemblage includes significant amounts of ferroactinolite, which are associated with low-grade schists and meta-igneous pelitic rocks, such as the Dalradian of Scotland or Caledonides of Norway (Bryhni and Andre' asson, 1985; Strachan et al., 2002). The mineral assemblage of chlorite, ferroactinolite, and biotite is diagnostic of the Greenschist Facies of the Caledonide rocks of southeast Norway or Scotland (Bryhni and Andre' asson, 1985). They are associated with epidote, chloritoid, albite, muscovite, calcite and dolomite. Calcite and dolomite are not durable and were therefore locally sourced. Chloritoid is present in Scottish metamorphic rocks. Epidote and hornblende occur in comparatively high percentages in LFA 1, in comparison to the other tills in eastern England. Epidote is most likely to be derived from the Greenschist mineral assemblage. Hornblende is associated with higher temperature metamorphism and igneous rocks (Hubert, 1971). This could potentially be sourced from the Epidote-Amphibolite facies, which underlies the Greenschist Facies in southern Norway (Bryhni and Andre' asson, 1985). Outcrops of epidote-amphibolite rocks also occur in the Southwest Highlands (Strachan et al., 2002), amphibolite facies metamorphic rocks occur in the Central Highlands, and there are granodiorite intrusions in Scotland and northern England.

The presence of rare minerals such as piedmontite also distinguishes LFA 1. Piedmontite is associated with low-grade schists, manganese ore deposits and hydrothermal metamorphism. The most likely source for this mineral is around Glen Coe (Strachan et al., 2002), although it is difficult to get this mineral across the ice divide into eastern Britain. This may have occurred over multiple glacial cycles, although it is not a particularly durable mineral, so this is unlikely. Piedmontite also occurs in schists in Scandinavia, and therefore this is an alternative source.

There are high percentages of monazite and hypersthene in LFA 1. Monazite is typical of acid igneous rocks and also occurs as a detrital phase in some sandstones (Hubert, 1971), and could be from Scotland or Scandinavia. Hypersthene is found in basic igneous rocks and gneisses, such as the Carboniferous basalts of Scotland or the Permian basaltic lavas of Oslofjord (Oftedahl, 1960; Stephenson and Gould, 1995). The pyroxenes and olivine minerals could be derived from Scottish mafic igneous rocks, although these minerals are not durable and are likely to have been derived from nearby sources, such as the Whin Sill Dolerite and Carboniferous volcanics in the Southern Uplands. The combination of the metamorphic minerals chloritoid, staurolite and garnet is indicative of Stonehavian metamorphism from northeast Scotland, close to the Highland Boundary Fault (Stephenson and Gould, 1995; Trewin, 2002).

The mixed lithological, mineralogical, and microfossil assemblages within LFA 1 suggest ice-rafting from a number of different regions. Trechmann's observations of a major Norwegian input into the Warren House Formation were not replicated in this study (cf. Trechmann, 1931), although the possible presence of 
Drammensgranit and a strongly metamorphic mineral presence supports a Norwegian influence. There is strong evidence of a northeasterly North Sea detrital material with Eocene palynomorphs, Triassic red marl, chalk and flint erratics. The Eocene palynomorphs are strong evidence of widespread erosion of Eocene strata adjacent to the central graben within the North Sea. These are the most easterly-derived lithologies found in LFA 1 and would logically have had to have involved the presence of the FIS in the nearby region.

There is strong evidence of north-eastern Scottish material, with slate, schist, and Grampian granites. There is a substantial component of syenite and granite, which could be derived from either Norway or Scotland. The low percentages of erratics typical of the Midland Valley of Scotland, such as Old Red Sandstone, and the low percentages of Carboniferous lithologies and fossils, imply that the ice did not extend very far to the south, and that the single Cheviot dolerite erratic could be recycled.

Mineralogically, LFA 2 strongly resembles LFA 1 . This sediment was probably derived by erosion and re-deposition of LFA 1 by coastal and marine processes. The rounded cobbles within Exposure B have a Pennine and local origin, and are probably reworked fluvial cobbles from inland Durham.

\subsection{Revised formal stratigraphic terminology for sediments at Warren House Gill}

The Warren House Formation of Thomas (1999) therefore requires redefinition. The name 'Ash Gill Member' is proposed here for the basal deposit of the 'Warren House Formation' (Thomas, 1999), interpreted here as a glaciomarine rainout diamicton subsequently overridden and subjected to glaciotectonic deformation. It contains primarily Scottish and North Sea detrital material. The Ash Gill Member is overlain by temperate-climate estuarine silts (LFA 2). They are also part of the Warren House Formation, and are here formally named the 'Whitesides Member' after the nearby minor valley, Whitesides Gill (see Fig. 2). The proposed stratigraphical scheme is summarised in Table 10.

\subsection{Wider implications for northwest European ice sheet history}

The occurrence of LFA 2 at 6-10 m above present sea level indicates a marine transgression at Warren House Gill, with subsequent uplift. Long-term uplift of the whole sequence has been proposed by other workers (Westaway, 2009b, 2009a), and the proposed Middle Pleistocene age suggests that there has been significant uplift since the palaeovalley was formed. Rapid uplift in northern England, in comparison to southern England as far north as Yorkshire, is suggested due to the greater mobility of the crust as a result of its younger thermal age and the heating effects of Palaeozoic granites, and isostatic uplift of the crust in response to Quaternary erosion. Westaway (2009a) argued that an MIS 7 age for the Easington Raised Beach, which has a height of $33 \mathrm{~m}$ O.D., means an uplift rate of $0.19 \mathrm{~mm}^{\text {a1 }}$ (Westaway, 2009a). This would normally mean that the older Ash Gill Member would be considerably higher in the landscape than the Easington Raised Beach. However, the landscape position of the Ash Gill Member can be reconciled as it was deposited in the base of a deep palaeovalley. Uplift of $81.7 \mathrm{~m}$ since MIS $12(0.19 \mathrm{~mm}$ a1 for 430,000 years; cf. Westaway, 2009a) would mean that the Ash Gill Member would now rest at sea level, and that the Easington Raised Beach would be at 33 m O.D. This is shown in Fig. 22.

Catt (1991b) suggested that the Warren House Formation could be correlated with the MIS 6 Bridlington Member (Basement Till) of Yorkshire, based on the presence of Scandinavian lithologies, the similar marine 
ostracods within the Bridlington Crag of the Bridlington Member and the Ash Gill Member, and an inferred pre-Ipswichian age (Trechmann, 1915; Catt and Penny, 1966; Francis, 1972; Catt, 2007). This is now viewed as unlikely, given an inferred MIS 8 to 12 age for the Ash Gill Member. It is also dangerous to assume that sediments of similar affinity would not have been deposited in most glaciations, meaning that the Ash Gill Member cannot be dated based on lithostratigraphic correlation alone.

During the initial English lowlands ice advance ice sheets sourced in Britain and Norway were calving into a glaciomarine embayment in the modern North Sea Basin. The buried palaeovalley of Warren House Gill was flooded with marine waters during advance of this ice sheet and the Ash Gill Member was deposited, with detrital material from Scotland, the North Sea Basin and Norway. Upward coarsening within the Ash Gill Member reflects the advancing ice margin. LF $1 \mathrm{~b}$ reflects glaciotectonic deformation by the advancing ice sheets. There is evidence of glaciomarine conditions in the North Sea Basin during MIS 6 or 8 in the Fisher Formation (Gatliff et al., 1994), and other workers have suggested evidence of glaciation in the North Sea during MIS 8 (Beets et al., 2005). There is widespread evidence of large-scale lowland glaciation in Britain during MIS 12 (Lunkka, 1994; Lewis et al., 1999; Fish and Whiteman, 2001; Lee et al., 2006), and if the Ash Gill Member was deposited during MIS 12, it could easily have occurred during an early phase and later been overridden by advancing ice sheets.

The overwhelmingly British and eastern North Sea provenance of the Ash Gill Member indicates that there is no evidence of an FIS in County Durham during MIS 6. The concept of a Scandinavian ice sheet reaching onshore eastern England prior to the British ice sheet, which would have had far less distance to travel, is difficult to uphold in the face of this new evidence. It is likely that the British Ice Sheet, advancing over the site at Warren House Gill as it continued to grow, would have quickly deflected the Scandinavian ice sheet, possibly coalescing in the low lying area of the North Sea. The FIS is thought to have interacted with the BIIS in the North Sea multiple times during the Quaternary, possibly deflecting the North Sea Lobe during MIS 2 (Davies et al., 2009b), the glaciation that deposited the Ash Gill Member (MIS 8 to 12), and during MIS 12, with evidence of (reworked) Scandinavian erratics in glacial deposits in Norfolk (Pawley et al., 2004; Hoare and Connell, 2005).

\section{Conclusions}

- The 'Warren House Formation' is redefined as comprising a glaciomarine rainout diamicton, defined here as the 'Ash Gill Member', overlain by pink estuarine silts (possibly reworked loess), the 'Whitesides Member'. The Ash Gill Member was subsequently overridden by at least the ice sheet which deposited it, and possibly again during later glaciations. The 'Whitesides Member' overlies the Ash Gill Member and was glaciotectonised at least during the Devensian glaciation. The Ash Gill Member is MIS 12 to MIS 8 in age.

- The Ash Gill Member formed in a deep palaeovalley, and was deposited in a glaciomarine environment by iceberg rafting and suspension settling from calving ice sheets situated in the North Sea Basin and onshore northern Britain, producing detrital material sourced from northeast Scotland and the northeast North Sea. 
- This research has therefore provided substantial new information regarding British lowland Middle and Upper Pleistocene glaciations during the Quaternary. The new scheme updates that proposed by Thomas (1999). This research supports recent work in Norfolk, which also suggests that is was no evidence of a Scandinavian ice sheet onshore in eastern England during MIS 6 or 12, although it may have frequently been active in the near offshore area (Lee et al., 2002, 2004b; Preece et al., 2009).

- Fennoscandian ice has interacted with the BIIS in the North Sea, close to eastern England, possibly multiple times during the Quaternary, though it is unlikely to have reached onshore Britain. Though a precise chronostratigraphical framework for these sediments is still under development, the interpretation of the Warren House Formation 'Ash Gill Member' as a Middle Pleistocene glaciomarine deposit, derived primarily from Scottish and North Sea sources, is significant. The overlying silts, the Whitesides Gill Member, are marine or estuarine, and reflect an ameliorating climate.

\section{Acknowledgements}

This research was conducted as part of a PhD programme by BJD at Durham University, and was funded by the Dudley Stamp Memorial Fund, the Research Development Fund from the Department of Geography, Durham University, and by the Hatfield Trust, Durham University. J.B. Riding publishes with the approval of the Executive Director, British Geological Survey (NERC). The authors thank Dr Simon Carr, Dr David Evans, Dr. Jonathon Lee, Dr Emrys Phillips and two anonymous reviewers for constructive and informative comments and discussions.

\section{References}

Aitken, M.J., 1985. Thermoluminescence Dating. Academic Press, London, 359 pp.

Aitken, M.J., 1998. An Introduction to Optical Dating. Oxford University Press, Oxford, 280 pp.

Allen, J.R.L., 1963. The classification of cross-stratified units, with notes on their origin. Sedimentology 2, 93-114.

Bateman, M.D., Catt, J.A., 1996. An absolute chronology for the raised beach and associated deposits at Sewerby, East Yorkshire, England. Journal of Quaternary Science 11, 389-395.

Baumann, K.-H., Lackschewitz, K.S., Mangerud, J., Spielhagen, R.F., Wolf-welling, T.C.W., Henrich, R., Kassens, H., 1995. Reflection of Scandinavian ice sheet fluctuations in Norwegian sea sediments during the past 150,000 years. Quaternary Research 43, 185-197.

Beaumont, P., 1967. The Glacial Deposits of Eastern Durham. Unpublished PhD Thesis, Department of Geography, Durham University, 568 pp.

Beets, D., Meijer, T., Beets, C., Cleveringa, P., Laban, C., van der Spek, A., 2005. Evidence for a middle Pleistocene glaciation of MIS 8 age in the southern north sea. Quaternary International 133-134, 7-19. 
Benn, D.I., 1994. Fabric strength and the interpretation of sedimentary fabric data. Journal of Sedimentary Research A64, 910-915.

Benn, D.I., 2004a. Clast morphology. In: Evans, D.J.A., Benn, D.I. (Eds.), A Practical Guide to the Study of Glacial Sediments. Arnold, London, pp. 77-92.

Benn, D.I., 2004b. Macrofabric. In: Evans, D.J.A., Benn, D.I. (Eds.), A Practical Guide to the Study of Glacial Sediments. Arnold, London, pp. 93-114.

Benn, D.I., 2007. Till fabric analysis. In: Elias, S.A. (Ed.), Encyclopedia of Quaternary Science. Elsevier, Amsterdam, pp. 954-959.

Benn, D.I., Evans, D.J.A., 1996. The interpretation and classification of subglacially-deformed materials. Quaternary Science Reviews 15, 23-52.

Berthelsen, A., 1979. Recumbent folds and boudinage structures formed by subglacial shear: an example of gravity tectonics. Geologie en Mijnbouw 58, 253-260.

Boswell, P.G.H., 1916. The Petrology of the North Sea Drift and the upper glacial Brickearths in east Anglia. Proceedings of the Geologists' Association 27, 78-98.

Boulton, G.S., Deynoux, M., 1981. Sedimentation in glacial environments and the identification of tills and tillites in ancient sedimentary sequences. Precambrian Research 15, 397-422.

Bowen, D.Q., 1999. On the Correlation and Classification of Quaternary Deposits and Land-sea Correlations, a Revised Correlation of Quaternary Deposits in the British Isles. Geological Society Special Report. Geological Society of London, London, pp. 1-10.

Bowen, D.Q., Phillips, F.M., McCabe, A.M., Knutz, P.C., Sykes, G.A., 2002. New data for the last glacial maximum in Great Britain and Ireland. Quaternary Science Reviews 21, 89-101.

Bowen, D.Q., Rose, J., McCabe, A.M., Sutherland, D.G., 1986. Correlation of Quaternary glaciations in England, Ireland, Scotland and Wales. Quaternary Science Reviews 5, 299-340.

Bowen, D.Q., Smith, D.B., Sykes, G.A., 1991. The age of the Easington raised beach, County Durham. Proceedings of the Yorkshire Geological Society 48, 415-420.

Bridgland, D.R. (Ed.), 1986. Clast Lithological Analysis. Technical Guide No. 3. Quaternary Research Association, Cambridge, 207 pp.

Bridgland, D.R., Austin, W.E.N., 1999. Shippersea Bay to Hawthorn Hive. In: Bridgland, D.R., Horton, B.P., Innes, J.B. (Eds.), The Quaternary of North-East England. Field Guide. Quaternary Research Association, London, pp. 51-56.

Bridgland, D.R., Schreve, D.C., Keen, D.H., Meyrick, R., Westaway, R., 2004. Biostratigraphical correlation between the late Quaternary sequence of the Thames and key fluvial localities in central Germany. Proceedings of the Geologists' Association 115, 125-140.

Briggs, L.I., McCulloch, D.S., Moser, F., 1962. The hydraulic shape of sand particles. Journal of Sedimentary Research 32, 645-656. 
Bryhni, I., Andre' asson, P.-G., 1985. Metamorphism in the Scandinavian Caledonides. In: Gee, D.G., Sturt, B.A. (Eds.), The Caledonide Orogen - Scandinavia and Related Areas. John Wiley \& Sons Ltd, Chichester, pp. 763-781.

Cameron, T.D.J., Crosby, A., Balson, P.S., Jeffery, D.H., Lott, G.K., Bulat, J., Harrison, D.J., 1992. United Kingdom Offshore Regional Report: The Geology of the Southern North Sea. HMSO, London, 149 pp.

Carney, J.N., 2007. Glacial deposits in the Trent valley. In: White, T.S., Bridgland, D.R., Howard, A.J., White, M.J. (Eds.), The Quaternary of the Trent Valley and Adjoining Regions. Field Guide. Quaternary Research Association, Cambridge, pp. 35-42.

Carr, S.J., 2001. Micromorphological criteria for distinguishing subglacial and glacimarine sediments: evidence from a contemporary tidewater glacier, Spitsbergen. Quaternary International 86, 71-79.

Carr, S.J., 2004. Micro-scale features and structures. In: Evans, D.J.A., Benn, D.I. (Eds.), A Practical Guide to the Study of Glacial Sediments. Arnold, London, pp. 115-144.

Carr, S.J., Holmes, R., van der Meer, J.J.M., Rose, J., 2006. The Last Glacial maximum in the North Sea: micromorphological evidence of extensive glaciation. Journal of Quaternary Science 21, 131-153.

Catt, J.A., 1991a. Late Devensian glacial deposits and glaciations in eastern England and the adjoining offshore region. In: Ehlers, J., Gibbard, P.L., Rose, J. (Eds.), Glacial Deposits in Great Britain and Ireland. A.A. Balkema, Rotterdam, pp. 61-68.

Catt, J.A., 1991b. The Quaternary history and glacial deposits of East Yorkshire. In: Ehlers, J., Gibbard, P., Rose, J. (Eds.), Glacial Deposits in Great Britain and Ireland. Balkema, Rotterdam, pp. 185-191.

Catt, J.A., 2001a. Dimlington cliff. In: Bateman, M.D., Buckland, P.C., Frederick, C.D., Whitehouse, N.J. (Eds.), The Quaternary of East Yorkshire and North Lincolnshire. Field Guide. Quaternary Research Association, London, pp. 53-68.

Catt, J.A., 2001b. Sewerby. In: Bateman, M.D., Buckland, P.C., Frederick, C.D., Whitehouse, N.J. (Eds.), The Quaternary of East Yorkshire and North Lincolnshire. Field Guide. Quaternary Research Association, London, pp. 83-88.

Catt, J.A., 2007. The Pleistocene glaciations of eastern Yorkshire: a review. Proceedings of the Yorkshire Geological Society 56, 177-208.

Catt, J.A., Digby, P.G.N., 1988. Boreholes in the Wolstonian Basement till at Easington, Holderness, July 1985. Proceedings of the Yorkshire Geological Society 47, 21-27.

Catt, J.A., Penny, L.F., 1966. The Pleistocene deposits of Holderness, east Yorkshire. Proceedings of the Yorkshire Geological Society 35, 375-420.

Davies, B.J. Heavy-mineral analysis: methods. In: Bridgland, D.R. (Ed.), Clast Analysis. Technical Guide. Quaternary Research Association, London, in press.

Davies, B.J., Bridgland, D.R., Roberts, D.H., OCofaigh, C., Pawley, S.M., Demarchi, B., Penkman, K.E.H., Austin, W., 2009a. The age and stratigraphic context of the Easington raised beach, County Durham, UK. Proceedings of the Geologists' Association 120, 183-198. 
Davies, B.J., Roberts, D.H., Bridgland, D.R., OCofaigh, C., Riding, J.B., Phillips, E.R., Teasdale, D.A., $2009 b$. Interlobate ice sheet dynamics during the last glacial maximum at Whitburn Bay, County Durham, England. Boreas 38, 555-575.

Davis, J.C., 1986. Statistics and Data Analysis in Geology, second ed.. John Wiley and Sons, New York, 646 pp.

Domack, E.W., 1984. Rhythmically bedded glaciomarine sediments on Whidbey Island, Washington. Journal of Sedimentary Petrology 54, 589-602.

Domack, E.W., Lawson, D.E., 1985. Pebble fabric in an ice-rafted diamicton. Journal of Geology 93, 577-591.

Ehlers, J., Gibbard, P.L., 1991. Anglian glaciation and glacial deposits in Britain. In: Ehlers, J., Gibbard, P.L., Rose, J. (Eds.), Glacial Deposits in Great Britain and Ireland. Balkema, Rotterdam, pp. 17-24.

Ehlers, J., Meyer, K.-D., Stephan, H.-J., 1984. The pre-Weichselian glaciations of north-West Europe. Quaternary Science Reviews 3, 1-40.

Eissmann, L., 2002. Quaternary Geology of eastern Germany (Saxony, Saxon-Anhalt, south Brandenburg, Thuringia), type area of the Elsterian and Saalian stages in Europe. Quaternary Science Reviews 21, $1275-1346$.

Evans, D., Owen, L., Roberts, D.H., 1995. Stratigraphy and sedimentology of Devensian (Dimlington Stadial) glacial deposits, east Yorkshire, England. Journal of Quaternary Science 10, 241-265.

Evans, D.J.A., Benn, D.I., 2004. Facies description and the logging of sedimentary exposures. In: Evans, D.J.A., Benn, D.I. (Eds.), A Practical Guide to the Study of Glacial Sediments. Arnold, London, pp. 11-50.

Evans, D.J.A., Phillips, E.R., Hiemstra, J.F., Auton, C.A., 2006. Subglacial till: formation, sedimentary characteristics and classification. Earth-Science Reviews 78, 115-176.

Eyles, C.H., Eyles, N., 1983. Sedimentation in a large lake: a reinterpretation of the late Pleistocene stratigraphy at Scarborough Bluffs, Ontario, Canada. Geology 11, 146-152.

Eyles, C.H., Eyles, N., Miall, A.D., 1985. Models of glaciomarine sediments and their application to the interpretation of ancient glacial sequences. Palaeogeography, Palaeoclimatology, Palaeoecology 15, 15-84.

Eyles, N., Eyles, C.H., McCabe, A.M., 1989. Sedimentation in an ice-contact subaqueous setting: the mid-Pleistocene 'North Sea Drifts' of Norfolk, U.K. Quaternary Science Reviews 8, 57-74.

Eyles, N., Lazorek, M., 2007. Glacial landforms, sediments. Glacigenic Lithofacies. In: Elias, S.A. (Ed.), Encyclopedia of Quaternary Science. Elsevier, Oxford, pp. 920-932.

Fish, P.R., Whiteman, C.A., 2001. Chalk micropalaeontology and the provenancing of Middle Pleistocene Lowestoft Formation till in eastern England. Earth Surface Processes and Landforms 26, 953-970.

Francis, E.A., 1972. Quaternary. In: Johnson, G.A.L., Hickling, G. (Eds.), Geology of Durham County. Transactions of the Natural History Society of Northumberland, Durham and Newcastle upon Tyne, vol. 41, pp. 134-153.

Gale, S.J., Hoare, P.G., 1991. Quaternary Sediments: Petrographic Methods for the Study of Unlithified Rocks. 
John Wiley \& Sons, New York, 323 pp.

Gale, S.J., Hoare, P.G., 1992. Bulk sampling of coarse clastic sediments for particle-size analysis. Earth Surface Processes and Landforms 17, 729-733.

Gatliff, R.W., Richards, P.C., Smith, K., Graham, C.C., McCormac, M., Smith, N.J.P., Long, D., Cameron, T.D.J., Evans, D., Stevenson, A.G., Bulat, J., Ritchie, J.D., 1994. The Geology of the Central North Sea. United Kingdom Offshore Regional Report. British Geological Survey. HMSO, London, 118 pp.

Gibbard, P.L., West, R.G., Andrew, R., Pettit, M., 1992. The margin of a Middle Pleistocene ice advance at Tottenhill, Norfolk, England. Geological Magazine 129, 59-76.

Goodfriend, G.A., BrighamGrette, J., Miller, G.H., 1996. Enhanced age resolution of the marine Quaternary record in the Arctic using aspartic acid racemization dating of bivalve shells. Quaternary Research 45, 176-187.

Hald, M., Korsun, S., 1997. Distribution of modern benthic foraminifera from fjords of Svalbard, European Arctic. Journal of Foraminiferal Research 27, 101-122.

Hamblin, R.J.O., Moorlock, B.S.P., Rose, J., Lee, J.R., Riding, J.B., Booth, S.J., Pawley, S.M., 2005. Revised Pre-Devensian glacial stratigraphy in Norfolk, England, based on mapping and till provenance. Netherlands Journal of Geosciences-Geologie En Mijnbouw 84, 77-85.

Hart, J.K., 2007. An investigation of subglacial shear zone processes from Weybourne, Norfolk, UK. Quaternary Science Reviews 26, 2354-2374.

Hart, J.K., Boulton, G.S., 1991. The interrelation of glaciotectonic and glaciodepositional processes within the glacial environment. Quaternary Science Reviews 10, 335-350.

Hart, J.K., Khatwa, A., Sammonds, P., 2004. The effect of grain texture on the occurrence of microstructural properties in subglacial till. Quaternary Science Reviews 23, 2501-2512.

Hart, J.K., Roberts, D.H., 1994. Criteria to distinguish between subglacial glaciotectonic and glaciomarine sedimentation: I - Deformation styles and sedimentology. Sedimentary Geology 91, 191-214.

Hicock, S.R., Fuller, E.A., 1995. Lobal interactions, rheologic superposition, and implications for a Pleistocene ice stream on the continental shelf of British Columbia. Geomorphology 14, 167-184.

Hiemstra, J.F., 2001. Microscopic analyses of Quaternary glacigenic sediments of Marguerite Bay, Antarctic Peninsula. Arctic Antarctic and Alpine Research 33, 258-265.

Hiemstra, J.F., Evans, D.J.A., Ó Cofaigh, C., 2007. The role of glacitectonic rafting and comminution in the production of subglacial tills: examples from southwest Ireland and Antarctica. Boreas 36, 386-399.

Hoare, P.G., Connell, E.R., 2005. The first appearance of Scandinavian indicators in East Anglia's glacial record. Bulletin of the Geological Society of Norfolk 54, 3-14.

Hoey, T.B., 2004. The size of sedimentary particles. In: Evans, D.J.A., Benn, D.I. (Eds.), A Practical Guide to the Study of Glacial Sediments. Arnold, London, pp. 51-76.

Horton, B.P., Edwards, R.J., 2006. Quantifying Holocene Sea-level Change Using Intertidal Foraminifera: 
Lessons from the British Isles. In: Cushman Foundation for Foraminiferal Research. Special Publication No. 40, $97 \mathrm{pp}$.

Houmark-Nielsen, M., Gibbard, J.E.a.P.L., 2004. The Pleistocene of Denmark: a Review of Stratigraphy and Glaciation History, Developments in Quaternary Science, vol. 2. Elsevier, Part 1, pp. 35-46.

Hubert, J.F., 1971. Analysis of heavy-mineral assemblages. In: Carver, R.E. (Ed.), Procedures in Sedimentary Petrology. Wiley-Interscience, New York, pp. 453-478.

Huuse, M., Lykke-Andersen, H., 2000. Overdeepened Quaternary valleys in the eastern Danish North Sea: morphology and origin. Quaternary Science Reviews 19, 1233-1253.

Jennings, A.E., Weiner, N.J., Helgadottir, G., Andrews, J.T., 2004. Modern foraminiferal faunas of the southwestern to northern Iceland shelf: oceanographic and environmental controls. Journal of Foraminiferal Research 34, 180-207.

Jones, A.P., Tucker, M.E., Hart, J.K., 1999. The Description and Analysis of Quaternary Stratigraphic Field Sections. In: Technical Guide No. 7. Quaternary Research Association, Cambridge, 293 pp.

Kaufman, D.S., Manley, W.F., 1998. A new procedure for determining DL amino acid ratios in fossils using reverse phase liquid chromatography. Quaternary Science Reviews 17, 987-1000.

Khatawa, A., Tulaczyk, S., 2001. Microstructural interpretations of modern and Pleistocene subglacially deformed sediments: the relative role of parent material and subglacial process. Journal of Quaternary Science 16, 507-517.

Kleman, J., Stroeven, A.P., 1997. Preglacial surface remnants and Quaternary glacial regimes in northwestern Sweden. Geomorphology 19, 35-54.

Knudsen, K.L., Sejrup, H.P., 1988. Amino acid geochronology of selected interglacial sites in the North Sea area. Boreas 17, 347-354. Kovach, W.L., 1995. Multivariate data analysis. In: Maddy, D., Brew, J.S. (Eds.), Statistical Modelling of Quaternary Science Data. Technical Guide No. 5. Quaternary Research Association, Cambridge, pp. 1-38.

Kristensen, T.B., Huuse, M., Piotrowski, J.A., Clausen, O.R., 2007. A morphometric analysis of tunnel valleys in the eastern North Sea based on 3D seismic data. Journal of Quaternary Science 22, 801-815.

Kruger, J., Kjaer, K.H., 1999. A data chart for field description and genetic interpretation of glacial diamicts and associated sediments - with examples from Greenland, Iceland, and Denmark. Boreas 28, 386-402.

Laban, C., 1995. The Pleistocene Glaciation in the Dutch Sector of the North Sea. A Synthesis of Sedimentary and Seismic Data. PhD thesis, 194 pp.

Lamplugh, G.W., 1891. On the drifts of Flamborough head. Quarterly Journal of the Geological Society, London 47, 384-431.

Langford, H.E., 2004. Post-Anglian drainage reorganisation affecting the Nene and Welland. In: Langford, H.E., Briant, R.M. (Eds.), Nene Valley Field Guide. Quaternary Research Association, London, pp. 36-43.

Langford, H.E., Briant, R.M., 2004. Post-Anglian Pleistocene deposits in the Peterborough area and the Pleistocene history of the Fen Basin. In: Langford, H.E., Briant, R.M. (Eds.), Nene Valley Field Guide. 
Quaternary Research Association, Cambridge, pp. 14-21.

Lee, J.R., 2003. Early and Middle Pleistocene Lithostratigraphy and Palaeoenvironments in Northern East Anglia, UK. Unpublished PhD thesis, Royal Holloway University of London, 421 pp.

Lee, J.R., Booth, S.J., Hamblin, R.J.O., Jarrow, A.M., Kessler, H.K.E., Moorlock, B.S.P., Morigi, A.M., Palmer, A., Pawley, S.M., Riding, J.B., Rose, J., 2004a. A new stratigraphy for the glacial deposits around Lowestoft, Great Yarmouth and Cromer, east Anglia, UK. Bulletin of the Geological Society of Norfolk 53, 3-60.

Lee, J.R., Phillips, E.R., 2008. Progressive soft sediment deformation within a subglacial shear zone - a hybrid mosaic-pervasive deformation model for Middle Pleistocene glaciotectonised sediments from eastern England. Quaternary Science Reviews 27, 1350-1362.

Lee, J.R., Rose, J., Candy, I., Barendregt, R.W., 2006. Sea-level changes, river activity, soil development and glaciation around the western margins of the southern North Sea Basin during the Early and early Middle Pleistocene: evidence from Pakefield, Suffolk, UK. Journal of Quaternary Science 21, 155-179.

Lee, J.R., Rose, J., Hamblin, R.J.O., Moorlock, B.S.P., 2004b. Dating the earliest lowland glaciation of eastern England: a pre-MIS 12 early Middle Pleistocene Happisburgh glaciation. Quaternary Science Reviews 23, 1551-1566.

Lee, J.R., Rose, J., Riding, J.B., Moorlock, B.S.P., Hamblin, R.J.O., 2002. Testing the case for a Middle Pleistocene Scandinavian glaciation in eastern England: evidence for a Scottish ice source for tills within the Corton Formation of east Anglia, UK. Boreas 31, 345-355.

Lewis, S.G., 1999. Eastern England. In: Bowen, D.Q. (Ed.), A Revised Correlation of Quaternary Deposits in the British Isles. Geological Society Special Report no. 23, pp. 10-27. London.

Lewis, S.G., Rose, J., Davies, H., 1999. Pre-Anglian fluvial and Anglian glaciogenic sediments, Knettishall, Suffolk, England. Proceedings of the Geologists Association 110, 17-32.

Lunkka, J.P., 1994. Sedimentation and lithostratigraphy of the North Sea Drift and Lowestoft Till formations in the coastal cliffs of northeast Norfolk, England. Journal of Quaternary Science 9, 209-233.

MacKenzie, W.S., Adams, A.E., 2001. A Colour Atlas of Rocks and Minerals in Thin Section. Manson Publishing, London, $192 \mathrm{pp}$.

Mange, M.A., Maurer, H.F.W., 1992. Heavy Minerals in Colour. Chapman and Hall, London, 147 pp.

Mania, D., 1995. The earliest occupation of Europe: the Elbe-Saale region (Germany). In: Roebroeks, W., Van Kolfschoten, T. (Eds.), The Earliest Occupation of Europe. University of Leiden, The Netherlands, pp. 85-110.

Manley, W.F., Miller, G.H., Czywcznski, J., 2000. Kinetics of aspartic acid racemisation in Mya and Hiatella; modelling age and paleotemperature of high-latitude Quaternary molluscs. In: Goodfriend, G.A., Collins, M.J., Fogel, M.L., Macko, S.A., Wehmiller, J.F. (Eds.), Perspectives in Amino Acid and Protein Geochemistry. Oxford University Press, Oxford, pp. 120-141.

McCabe, A.M., Bowen, D.Q., Penney, D.N., 1993. Glaciomarine facies from the western sector of the last British ice sheet, Malin Beg, County Donegal, Ireland. Quaternary Science Reviews 12, 35-45. 
McCarroll, D., Harris, C., 1992. The glacigenic deposits of western Lleyn, North Wales: terrestrial or marine? Journal of Quaternary Science 7, 19-29.

Meijer, T., Cleveringa, P., 2009. Aminostratigraphy of middle and late Pleistocene deposits in the Netherlands and the southern part of the north Sea Basin. Global and Planetary Change. doi:10.1016/j.gloplacha.2009.03.004 1.

Mejdahl, V., 1979. Thermoluminescence dating: beta attenuation in quartz grains. Archaometry 21, 61-73.

Menzies, J., 2000. Micromorphological analyses of microfabrics and microstructures indicative of deformation processes in glacial sediments. In: Maltman, A.J., Hubbard, A.J., Hambrey, M.J. (Eds.), Deformation of Glacial Materials. Geological Society Special Publication 176, vol. 176. Geological Society of London, London, pp. 245-257.

Menzies, J., Maltman, A.J., 1992. Microstructures in diamictons -evidence of subglacial bed conditions. Geomorphology 6, 27-40.

Menzies, J., van der Meer, J.J.M., Rose, J., 2006. Till-as a glacial "tectomict", its internal architecture, and the development of a "typing" method for till differentiation. Geomorphology 75, 172-200.

Merritt, J.W., Auton, C.A., Firth, C.R., 1995. Ice-proximal glaciomarine sedimentation and sea-level change in the Inverness area, Scotland: a review of the deglaciation of a major ice stream of the British Late Devensian ice sheet. Quaternary Science Reviews 14, 289-329.

Mills, P.C., 1983. Genesis and diagnostic value of soft-sediment deformation structures - a review. Sedimentary Geology 35, 83-104.

Morton, A.C., 1985. A new approach to provenance studies: electron microprobe analysis of detrital garnets from Middle Jurassic sandstones of the northern North Sea. Sedimentology 32, 553-566.

Morton, A.C., Hallsworth, A.C., 1994. Identifying provenance-specific features of detrital heavy mineral assemblages in sandstones. Sedimentary Geology 90, 241-256.

Morton, A.C., Hallsworth, A.C., 2007. Stability of detrital heavy minerals during burial diagenesis. In: Mange, M.A., Wright, D.T. (Eds.), Heavy Minerals in Use. Developments in Sedimentology 58, vol. 58. Elsevier, pp. 215-245.

Murray, A.S., Roberts, R.G., 1997. Determining the burial time of single grains of quartz using optically stimulated luminescence. Earth and Planetary Science Letters 32, 57-73.

Murray, A.S., Wintle, A.G., 2000. Luminescence dating of quartz using an improved single-aliquot regenerative-dose protocol. Radiation Measurements 32, 57-73.

van der Meer, J.J.M., 1993. Microscopic evidence of subglacial deformation. Quaternary Science Reviews 16, 827-831.

van der Meer, J.J.M., 1997. Particle and aggregate mobility in till: microscopic evidence of subglacial processes. Quaternary Science Reviews 16, 827-831. OCofaigh, C., Dowdeswell, J.A., 2001. Laminated sediments in glacimarine environments: diagnostic criteria for their interpretation. Quaternary Science Reviews 20, 1411-1436. 
Ó Cofaigh, C., Evans, D.J.A., Hiemstra, J., 2008. Till sedimentology and stratigraphy on the Dingle Peninsula, SW Ireland: implications for Late Quaternary regional ice flow patterns. Proceedings of the Geologists' Association 119, 137-152.

Oftedahl, C., 1960. Permian igneous rocks of the Oslo graben, Norway. Guide to excursions A.11 and C.7. In: International Geological Congress XXI Session, Norden, 1960.

Passchier, S., 2007. The use of heavy minerals in the reconstruction of ice-sheet drainage patterns: an example from the edge of the East Antarctic Ice Sheet. In: Mange, M.A., Wright, D.T. (Eds.), Heavy Minerals in Use. Developments in Sedimentology 58. Elsevier, pp. 677-699.

Pawley, S.M., Bailey, R.M., Rose, J., Moorlock, B.S.P., Hamblin, R.J.O., Booth, S.J., Lee, J.R., 2008. Age limits on Middle Pleistocene glacial sediments from OSL dating, north Norfolk, UK. Quaternary Science Reviews 27, 1363-1377.

Pawley, S.M., Rose, J., Lee, J.R., Moorlock, B.S.P., Hamblin, R.J., 2004. Middle Pleistocene sedimentology and lithostratigraphy of Weybourne, northeast Norfolk, England. Proceedings of the Geologists Association $115,25-42$.

Penkman, K.E.H., Kaufman, D.S., Maddy, D., Collins, M.J., 2008. Closed-system behaviour of the intra-crystalline fraction of amino acids in mollusc shells. Quaternary Geochronology 3, 2-25.

Penkman, K.E.H., Preece, R.C., Keen, D.H., Maddy, D., Schreve, D.C., Collins, M., 2007a. Amino acids from the intra-crystalline fraction of mollusc shells: applications to geochronology. Quaternary Science Reviews 26, 2958-2969.

Penkman, K.E.H., Preece, R.C., Keen, D.H., Maddy, D., Schreve, D.C., Collins, M.J., 2007b. Testing the aminostratigraphy of fluvial archives: the evidence from intra-crystalline proteins within freshwater shells. Quaternary Science Reviews 26, 2958-2969.

Perrin, R.M.S., Rose, J., Davies, H., 1979. The distribution, variation and origins of pre-Devensian tills in Eastern England. Philosophical Transactions of the Royal Society of London B 275, 535-570.

Phillips, E., Lee, J.R., Burke, H., 2008. Progressive proglacial to subglacial deformation and syntectonic sedimentation at the margins of the Mid-Pleistocene British Ice Sheet: evidence from north Norfolk, UK. Quaternary Science Reviews 27, 1848-1871.

Phillips, E., Merritt, J., Auton, C., Golledge, N., 2007. Microstructures in subglacial and proglacial sediments: understanding faults, folds and fabrics, and the influence of water on the style of deformation. Quaternary Science Reviews 26, 1499-1528.

Phillips, E.R., Evans, D.J.A., Auton, C.A., 2002. Polyphase deformation at an oscillating ice margin following the Loch Lomond Readvance, central Scotland, UK. Sedimentary Geology 149, 157-182.

Piotrowski, J.A., Kraus, A.M., 1997. Response of sediment to ice sheet loading in northwestern Germany: effective stresses and glacier-bed stability. Journal of Glaciology 43, 495-502.

Powell, A.J., 1992. Dinoflagellate cysts of the Tertiary system. In: Powell, A.J. (Ed.), A Stratigraphic Index of Dinoflagellate Cysts. Chapman and Hall, London, pp. 155-251. 
Powell, R.D., 1984. Glacimarine processes and inductive lithofacies modelling of ice shelf and tidewater glacier sediments based on Quaternary examples. Marine Geology 57, 1-52.

Powell, R.D., Molnia, B.F., 1989. Glacimarine sedimentary processes, facies and morphology of the south-southeast Alaska shelf and fjords. Marine Geology 85, 359-390.

Praeg, D., 2003. Seismic imaging of Mid-Pleistocene tunnel-valleys in the North Sea Basin-high resolution from low frequencies. Journal of Applied Geophysics 53, 273-298.

Preece, R.C., Parfitt, S.A., Coope, G.R., Penkman, K.E.H., Ponel, P., Whittaker, J.E., 2009. Biostratigraphic and aminostratigraphic constraints on the age of the Middle Pleistocene glacial succession in north Norfolk, UK. Journal of Quaternary Science 24, 557-580.

Prescott, J.R., Hutton, J.T., 1994. Cosmic ray contributions to dose rates for luminescence and ESR dating: large depths and long-term variations. Radiation Measurements 23, 497-500.

Riding, J.B., 2007. A Palynological Investigation of Diamictons and Tills From Northeast England. Internal Report IR/07/021R. British Geological Survey Internal Report, Nottingham, 9 pp.

Riding, J.B., Rose, J., Booth, S.J., 2003. Allochthonous and indigenous palynomorphs from the Devensian of the Warham Borehole, Stiffkey, north Norfolk, England: evidence for sediment provenance. Proceedings of the Yorkshire Geological Society 54, 223-235.

Rijsdijk, K.F., Passchier, S., Weerts, H.J.T., Laban, C., van Leeuwen, R.J.W., Ebbing, J.H.J., 2005. Revised Upper Cenozoic stratigraphy of the Dutch sector of the North Sea Basin: towards an integrated lithostratigraphic, seismostratigraphic and allostratigraphic approach. Netherlands Journal of Geosciences-Geologie En Mijnbouw 84, 129-146.

Roberts, D.H., Hart, J.K., 2005. The deforming bed characteristics of a stratified till assemblage in north East Anglia, UK: investigating controls on sediment rheology and strain signatures. Quaternary Science Reviews 24, 123-140.

Ryan, P.D., Mange, M.A., Dewey, J.F., 2007. Statistical analysis of high-resolution heavy mineral stratigraphic data from the Ordovician of Western Ireland and its tectonic consequences. In: Mange, M.A., Wright, D.T. (Eds.), Heavy Minerals in Use. Developments in Sedimentology 58. Elsevier, pp. 465-489.

Schreve, D.C., Bridgland, D.R., 2002. Correlation of English and German Middle Pleistocene fluvial sequences based on mammalian biostratigraphy. Geologie En Mijnbouw-Netherlands Journal of Geosciences 81, 357-373.

Sejrup, H.P., Hjelstuen, B.O., Torbjorn Dahlgren, K.I., Haflidason, H., Kuijpers, A., Nygard, A., Praeg, D., Stoker, M.S., Vorren, T.O., 2005. Pleistocene glacial history of the NW European continental margin. Marine and Petroleum Geology 22, 1111-1129.

Sejrup, H.P., Nygård, A., Hall, A.M., Haflidason, H., 2009. Middle and Late Weichselian (Devensian) glaciation history of south-western Norway, North Sea and eastern UK. Quaternary Science Reviews 28, 370-380.

Smed, P., Ehlers, J., 1994. Steine aus dem Norden. Borntraeder, G., Berlin, 194 pp.

Smith, D.B., Francis, E.A., 1967. Geology of the Country between Durham and West Hartlepool. Memoirs of 
the Geological Survey of Great Britain. In: Explanation of One-inch Geological Sheet 27, New Series. Her Majesty's Stationary Office, London, 354 pp.

Stephenson, D., Gould, D., 1995. British Regional Geology: The Grampian Highlands. Memoir of the British Geological Survey, fourth ed. Her Majesty's Stationery Office, London, 262 pp.

Strachan, R.A., Stewart, A.D., Wright, D.T., 2002. The northern Highland and Grampian Terranes. In: Trewin, N.H. (Ed.), Geology of Scotland, fourth ed.. Geological Society of London, Bath, pp. 81-148.

Thamó-Bozsó, E., Kovács, L.Ó ., 2007. Evolution of Quaternary to Modern Fluvial network in the Mid-Hungarian plain, indicated by heavy mineral distributions and statistical analysis of heavy mineral data. In: Mange, M.A., Wright, D.T. (Eds.), Heavy Minerals in Use. Developments in Sedimentology, vol. 58. Elsevier, pp. 491-513.

Thomas, G.S.P., 1999. Northern England. In: Bowen, D.Q. (Ed.), A Revised Correlation of Quaternary Deposits in the British Isles. Geological Society, London, pp. 91-98. Special Report 23.

Trechmann, C.T., 1915. The Scandinavian Drift of the Durham coast and the general glaciology of south-east Durham. Quarterly Journal of Geological Society of London 71, 53-83.

Trechmann, C.T., 1931. The Scandinavian Drift or Basement clay on the Durham coast. Proceedings of the Geologists' Association 42, 292-294.

Trechmann, C.T., 1952. On the Pleistocene of east Durham. Proceedings of the Yorkshire Geological Society 28, 164-179.

Trewin, N.H., 2002. The Geology of Scotland, fourth ed. The Geological Society of London, London, 576 pp.

Urban, B., 1995. Palynological evidence of younger Middle Pleistocene interglacials (Holsteinian, Reinsdorf and Scö ningen) in the Schöningen open cast lignite mine (eastern lower Saxony, Germany). Mededelingen Rijks Geologische Dienst 52, 175-185.

van der Wateren, F.M., 1995. Processes of glaciotectonism. In: Menzies, J. (Ed.), Modern Glacial Environments: Processes, Dynamics and Sediments. Butter-man-Heinemann, Oxford, pp. 309-335.

van der Wateren, F.M., Kluiving, S.J., Bartek, L.R., 2000. Kinematic indicators of subglacial shearing. In: Maltman, A.J., Hubbard, B., Hambrey, M.J. (Eds.), Deformation of Glacial Materials. Geological Society, London, Special Publication, vol. 176, pp. 259-278. London.

Walden, J.S., 2004. Particle Lithology (or mineral and geochemical analysis). In: Evans, D.J.A., Benn, D.I. (Eds.), A Practical Guide to the Study of Glacial Sediments. Arnold, London, pp. 145-180.

Westaway, R., 2009a. Quaternary uplift of northern England. Global and Planetary Change 68, 357-382.

Westaway, R., 2009b. Quaternary vertical crustal motion and drainage evolution in East Anglia and adjoining parts of southern England: chronology of the Ingham River terrace deposits. Boreas 38, 261-284.

White, T.S., Bridgland, D.R., Howard, A.J., Westaway, R., White, M.J. Evidence from the Trent terrace archive for lowland glaciation of Britain during the Middle and Late Pleistocene. Proceedings of the Geologists' Association, submitted. 
Wilson, S.J., 1991. The correlation of the Speeton shell bed, Filey Bay, Yorkshire, to an oxygen isotope stage. Proceedings of the Yorkshire Geological Society 48, 223-226.

Woolacott, D., 1900. On the boulder clay, raised beaches, and associated phenomena in the east of Durham. Proceedings of the University of Durham Philosophical Society 1, 247-258. 


\section{Tables}

Table 1. Research through time of the basal deposit at Warren House Gill.

\begin{tabular}{|l|l|l|l|}
\hline $\begin{array}{l}\text { Name of } \\
\text { Sediment }\end{array}$ & Age & Process & Author \\
\hline $\begin{array}{l}\text { Scandinavian } \\
\text { Drift }\end{array}$ & $\begin{array}{l}\text { 'Older } \\
\text { Glaciation' }\end{array}$ & $\begin{array}{l}\text { Scandinavian } \\
\text { subglacial till }\end{array}$ & $\begin{array}{l}\text { Trechmann, 1915, Trechmann, 1931 and Trechmann, } \\
1952\end{array}$ \\
\hline $\begin{array}{l}\text { Scandinavian } \\
\text { Drift }\end{array}$ & MIS 6 & $\begin{array}{l}\text { Scandinavian ice } \\
\text { shelf }\end{array}$ & Beaumont 1967 \\
\hline $\begin{array}{l}\text { Warren House } \\
\text { Till }\end{array}$ & MIS 6 & $\begin{array}{l}\text { Scandinavian } \\
\text { Subglacial till }\end{array}$ & Smith and Francis 1967 \\
\hline $\begin{array}{l}\text { Warren House } \\
\text { Formation }\end{array}$ & MIS 6 & $\begin{array}{l}\text { Scandinavian } \\
\text { Subglacial till }\end{array}$ & Thomas 1999 \\
\hline
\end{tabular}

Table 2. Micromorphological summary of thin sections of LFAs 1 and 2 at Warren House Gill.

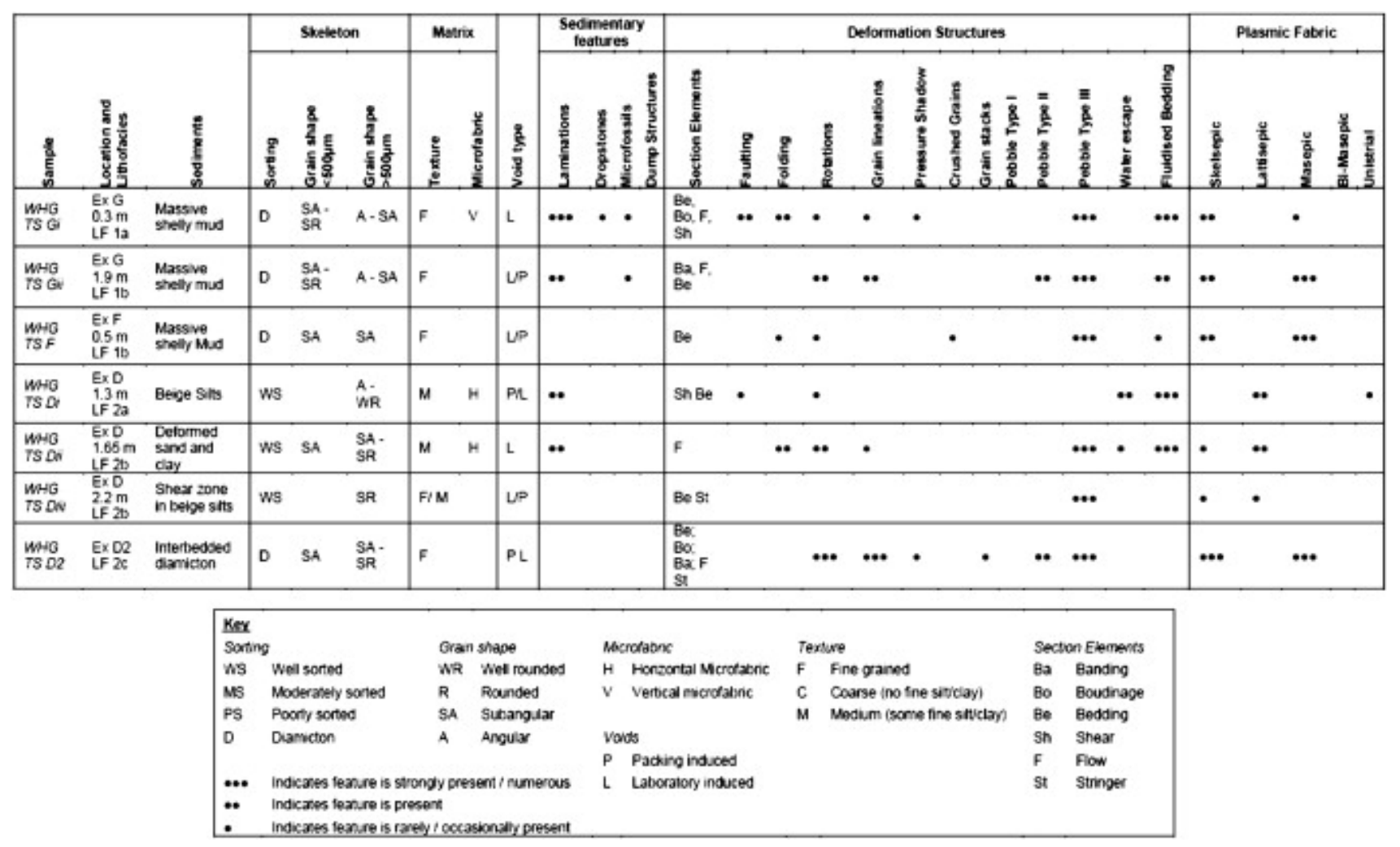


Table 3. Particle-size analysis of sediments at Warren House Gill.

\begin{tabular}{|l|r|r|r|r|r|r|}
\hline Particle diameter & \multicolumn{1}{l|}{ LFA 1 } & \multicolumn{1}{l|}{ LFA 2 } & \multicolumn{1}{l|}{ LF 3a } & \multicolumn{1}{l|}{ LF 4a } & \multicolumn{1}{l|}{ LF 4b } & \multicolumn{1}{l|}{ LFA 5 } \\
\hline \% Clay $(>3.9 \mu \mathrm{m})$ & 27.06 & 11.58 & 17.51 & 4.3 & 1.9 & 9.55 \\
\hline \% Silt $(3.9-63 \mu \mathrm{m})$ & 40.22 & 77.97 & 33.5 & 27.63 & 4.22 & 8.91 \\
\hline \% Fine sand $(63-500 \mu \mathrm{m})$ & 26.46 & 9.33 & 26.41 & 68.08 & 7.04 & 26.45 \\
\hline \% Coarse sand $(500 \mu \mathrm{m}-2 \mathrm{~mm})$ & 6.42 & 1.12 & 9.05 & 0 & 8.27 & 12.65 \\
\hline \% Fine gravel $(2 \mathrm{~mm}-8 \mathrm{~mm})$ & 0.72 & 0 & 8.32 & 0 & 28.49 & 17.5 \\
\hline \% Coarse gravel $(8 \mathrm{~mm}-31.5 \mathrm{~mm})$ & 1.11 & 0 & 6.21 & 0 & 50.08 & 24.94 \\
\hline
\end{tabular}

Table 4. Particle-size analysis of LFA 1 at Warren House Gill, with some LF 3a sample included for comparison

\begin{tabular}{|c|c|c|c|c|c|c|c|}
\hline Particle diameter & $\begin{array}{l}\text { WHG } \\
\text { G1LF 1a }\end{array}$ & $\begin{array}{l}\text { WHG } \\
\text { G2LF 1a }\end{array}$ & $\begin{array}{l}\text { WHG } \\
\text { G3LF 1b }\end{array}$ & $\begin{array}{l}\text { WHG F1LF } \\
\text { 1b }\end{array}$ & $\begin{array}{l}\text { WHG F3LF } \\
3 a\end{array}$ & $\begin{array}{l}\text { WHG } \\
\text { G4LF 3a }\end{array}$ & $\begin{array}{l}\text { WHG C3LF } \\
3 a\end{array}$ \\
\hline Sample height (metres O.D.) & 8.5 & 10 & 11 & 12.5 & 15 & 18.5 & 31 \\
\hline Original sample weight (g) & 8580 & 10195 & 4380 & 16730 & 6280 & 6740 & 6500 \\
\hline$\%$ Clay $(>3.9 \mu \mathrm{m})$ & 26.74 & 26.96 & 28.45 & 27.09 & 17.77 & 14.65 & 24.67 \\
\hline$\%$ Silt $(3.9-63 \mu \mathrm{m})$ & 49.25 & 42.61 & 43.37 & 26.67 & 29.21 & 29.91 & 37.6 \\
\hline$\%$ Fine sand $(63-500 \mu \mathrm{m})$ & 18.6 & 21.56 & 21.02 & 40.68 & 31.04 & 32.84 & 18.23 \\
\hline $\begin{array}{l}\text { \% Coarse sand (500 } \mu \mathrm{m}-2 \\
\mathrm{~mm})\end{array}$ & 4.35 & 8.24 & 6.89 & 1.57 & 1.63 & 6.88 & 5.11 \\
\hline$\%$ Fine gravel (2 mm - $8 \mathrm{~mm})$ & 0.61 & 0.73 & 0.89 & 0.98 & 6.61 & 7.55 & 6.43 \\
\hline $\begin{array}{l}\text { \% Coarse gravel ( } 8 \mathrm{~mm}-31.5 \\
\mathrm{~mm})\end{array}$ & 0.44 & 0.91 & 0.38 & 4.01 & 14.75 & 9.17 & 7.97 \\
\hline
\end{tabular}


Table 5. Average percentage (non-opaques) heavy-minerals at Warren House Gill, 63-250 $\mu \mathrm{m}$ fraction. The means of multiple samples from the same lithofacies are shown. The minerals are grouped with minerals of a similar chemical nature and of a similar provenance.

\begin{tabular}{|c|c|c|c|c|c|c|}
\hline & Heavy-mineral phase & LFA 1 & LFA 2 & LFA 3 & LFA 4 & LFA 5 \\
\hline & $n$ & 4646 & 1204 & 21276 & 6346 & 2058 \\
\hline & $\%$ Opaques & 38.7 & 44.3 & 78 & 73.8 & 76.2 \\
\hline & \% Non-opaques & 61.3 & 56.8 & 22 & 26.2 & 24.8 \\
\hline & $\%$ Heavy-minerals & 0.8 & 0.4 & 1.3 & 0.7 & 1.7 \\
\hline \multicolumn{7}{|c|}{ Ferromagnesian minerals } \\
\hline & Olivine & 2.7 & 1 & 1.7 & 1.6 & 2.5 \\
\hline \multirow{3}{*}{ Pyroxene Group } & Enstatite & 1.3 & 1.1 & 1.1 & 0.5 & 0.2 \\
\hline & Hypersthene & 4.4 & 1.5 & 1.2 & 0.2 & 0.5 \\
\hline & Clinopyroxene & 4.6 & 9.9 & 4.8 & 1.5 & 1.3 \\
\hline \multirow{3}{*}{ Amphibole Group } & Tremolite & 0 & 0 & 0 & 0.1 & 0 \\
\hline & Ferroactinolite/actinolite & 9 & 0.4 & 1.5 & 0 & 0 \\
\hline & Hornblende & 3.6 & 3 & 0.7 & 0.6 & 0 \\
\hline \multicolumn{7}{|c|}{ Phyllosilicate minerals } \\
\hline & Muscovite & 4.1 & 3.2 & 7.5 & 6.8 & 4.5 \\
\hline & Glauconite & 0.9 & 0 & 0.2 & 0.1 & 0 \\
\hline & Biotite & 4 & 16.1 & 9 & 11.2 & 2.3 \\
\hline & Chlorite & 1.4 & 6.1 & 4.1 & 4.2 & 0.5 \\
\hline \multicolumn{7}{|c|}{ Metasedimentary index minerals } \\
\hline & Garnet & 16.9 & 17.1 & 12.7 & 14.2 & 28.7 \\
\hline & Staurolite & 1.1 & 0.2 & 0.5 & 0.6 & 0 \\
\hline & Chloritoid & 2.8 & 0.1 & 0.6 & 0.2 & 0 \\
\hline \multirow{3}{*}{ Aluminium silicates } & Sillimanite & 2 & 1.1 & 1.6 & 0.1 & 1.4 \\
\hline & Andalusite & 2 & 1.5 & 6.3 & 4.9 & 0.7 \\
\hline & Kyanite & 2.2 & 1.1 & 7 & 7.3 & 4.1 \\
\hline \multicolumn{7}{|c|}{ Epidote Group minerals } \\
\hline & Zoisite/Clinozoisite & 4.5 & 6.1 & 6.3 & 8.7 & 7.4 \\
\hline & Piedmontite & 0.1 & 0 & 0 & 0 & 0 \\
\hline & Epidote & 8.2 & 14.4 & 4.4 & 1.2 & 2.3 \\
\hline & Axinite & 1.5 & 2 & 0.1 & 0.1 & 0 \\
\hline \multicolumn{7}{|c|}{ Other detrital minerals } \\
\hline & Zircon & 2.5 & 0.5 & 4.3 & 4 & 16 \\
\hline & Titanite & 7.6 & 6.6 & 2.1 & 0.5 & 3.4 \\
\hline & Tourmaline & 2 & 1.6 & 1.8 & 3.6 & 4.3 \\
\hline & Pumpellyite & 0 & 0 & 0.5 & 0 & 0 \\
\hline \multirow{4}{*}{ Oxides } & Rutile & 0.8 & 0.3 & 2 & 1.8 & 4.6 \\
\hline & Brookite & 0.8 & 0.8 & 1.6 & 4 & 6.8 \\
\hline & Spinel & 0.1 & 0 & 0.2 & 0.2 & 0.2 \\
\hline & Anatase & 0.3 & 0 & 0.2 & 0.5 & 0 \\
\hline Carbonates & Dolomite/Calcite & 1.7 & 3 & 16.6 & 19.4 & 4.6 \\
\hline Sulphates & Baryte & 0 & 0 & 0 & 0.3 & 0 \\
\hline \multirow{2}{*}{ Phosphates } & Apatite & 2.3 & 2.6 & 1.9 & 2.7 & 4.5 \\
\hline & Monazite & 7 & 0.8 & 1.1 & 0.3 & 0.2 \\
\hline
\end{tabular}


Table 6. Clast-lithological analysis of sediments at Warren House Gill and the Easington Raised Beach (please refer to Davies et al., 2009a for more detail on the Easington Raised Beach).

\begin{tabular}{|c|c|c|c|c|c|c|}
\hline & \multirow{2}{*}{ Lithofacies Association } & \multicolumn{4}{|c|}{ Warren House Gill } & \multirow{2}{*}{$\begin{array}{l}\text { Easington } \\
\text { Raised Beach }\end{array}$} \\
\hline & & LF 1b & LF 3a & LF 4b & LFA 5 & \\
\hline & $n$ & 710 & 3212 & 677 & 263 & 2743 \\
\hline \multirow{8}{*}{ Igneous } & Diorite & 0.5 & 0 & 0 & 0 & 0 \\
\hline & Granite & 3.7 & 0.5 & 0.6 & 0 & 1 \\
\hline & Gabbro & 0 & 0 & 0 & 0 & 0 \\
\hline & Rhyolite & 1.4 & 0.5 & 0.3 & 0 & 0.9 \\
\hline & Andesite & 2.1 & 0.2 & 0.2 & 0.4 & 0.1 \\
\hline & Basalt & 0.2 & 0 & 0 & 0 & 0 \\
\hline & Porphyry & 1.2 & 0.2 & 1.3 & 0.4 & 5 \\
\hline & Felsite & 0.3 & 0.1 & 0 & 0 & 0 \\
\hline \multirow{3}{*}{ Metamorphic } & Gneiss & 0.3 & 0 & 0 & 0 & 0 \\
\hline & Slate & 0.3 & 0 & 0 & 0 & 0 \\
\hline & Schist & 0.2 & 0 & 0 & 0 & 0 \\
\hline \multirow{6}{*}{$\begin{array}{c}\text { Sandstone, Siltstone } \\
\text { and Breccia }\end{array}$} & Sandstone (undifferentiated) & 2 & 11 & 4.7 & 1.9 & 0.1 \\
\hline & Quartzitic Sandstone & 1.5 & 1.7 & 2.2 & 3 & 0 \\
\hline & Siltstone & 0.2 & 0.7 & 0 & 0 & 0 \\
\hline & Breccia & 0.1 & 0 & 0 & 0 & 0 \\
\hline & Old Red Sandstone & 0 & 0.3 & 0.3 & 0 & 0 \\
\hline & Greywacke & 0.8 & 6.8 & 4.9 & 4.2 & 0.1 \\
\hline \multirow{6}{*}{ Quartzite } & Brown orthoquartzite & 2 & 1.3 & 0.2 & 0.8 & 0.3 \\
\hline & Red orthoquartzite & 0.5 & 0.2 & 0 & 0 & 1.3 \\
\hline & White orthoquartzite & 7.5 & 0.3 & 1.2 & 0 & 3.4 \\
\hline & Brown Vein Quartz & 0.9 & 0.1 & 0 & 0 & 0.2 \\
\hline & Red Vein Quartz & 0.5 & 0 & 0 & 0 & 0.1 \\
\hline & White Vein Quartz & 7 & 0.5 & 0.9 & 0 & 4.1 \\
\hline \multirow{2}{*}{ Cretaceous } & Flint & 3.9 & 0 & 0 & 0 & 2.2 \\
\hline & Chalk & 2.5 & 0 & 0 & 0 & 0.1 \\
\hline \multirow{2}{*}{ Jurassic } & Ironstone & 0 & 0.3 & 0 & 0.8 & 0 \\
\hline & Mudstone & 0.1 & 1.2 & 0.6 & 0 & 0 \\
\hline Triassic & Red Marl & 3.3 & 0.2 & 0 & 0 & 0 \\
\hline \multirow{4}{*}{ Permian } & Magnesian Limestone & 52.6 & 68.3 & 70.3 & 76.8 & 80.9 \\
\hline & Yellow Sands & 0.1 & 1.1 & 0 & 0 & 0.4 \\
\hline & Whin Sill Dolerite & 1.1 & 0.7 & 1.9 & 1.1 & 0.1 \\
\hline & New Red Sandstone & 0 & 0 & 0 & 0 & 0 \\
\hline \multirow{4}{*}{ Carboniferous } & Carboniferous Limestone & 3 & 3.4 & 10.6 & 9.9 & 0.7 \\
\hline & Chert & 0.1 & 0 & 0 & 0 & 0 \\
\hline & Coal & 0.2 & 1.2 & 0 & 0.8 & 0 \\
\hline & Shale & 0 & 0.1 & 0 & 0 & 0 \\
\hline
\end{tabular}


Table 7. Age-diagnostic palynomorph analysis of LF 1b and LF 3a (from Riding, 2007).

\begin{tabular}{|l|l|l|}
\hline Sample & LF 1b & LF 3a \\
\hline Carboniferous spores & $33(2.3 \%)$ & c. $99 \%$ \\
\hline Jurassic dinoflagellate cysts & $1(0.1 \%)$ & - \\
\hline Late Cretaceous palynomorphs & $4(0.3 \%)$ & - \\
\hline Eocene dinoflagellate cysts & $168(11.8 \%)$ & - \\
\hline Quaternary spores and pollen & $1045(73.4 \%)$ & c. $1 \%$ \\
\hline Non age-diagnostic palynomorphs & $172(12.1 \%)$ & - \\
\hline
\end{tabular}

Table 8. Amino acid data on Hiatella shells from Warren House Gill. Error terms represent 1 S.D. about the mean for the duplicate analyses for an individual sample. Each sample was bleached (b), with the free amino acid fraction signified by ' $\mathrm{F}$ ' and the total hydrolysable fraction by ' $\mathrm{H}{ }^{*}$ '.

\begin{tabular}{|c|c|c|c|c|c|c|}
\hline NEaar $n^{\circ}$ & Sample name & Asx D/L & Glx D/L & Ala D/L & Val D/L & [Ser]/[Ala] \\
\hline $4688 \mathrm{bF}$ & WHG09Hi01bF & $0.730 \pm 0.007$ & $0.552 \pm 0.003$ & $0.824 \pm 0.006$ & $0.561 \pm 0.011$ & $0.067 \pm 0.002$ \\
\hline $4688 \mathrm{bH}^{*}$ & WHG09Hi01bH* & $0.550 \pm 0.001$ & $0.364 \pm 0.009$ & $0.652 \pm 0.003$ & $0.433 \pm 0.018$ & $0.181 \pm 0.002$ \\
\hline $4689 \mathrm{bF}$ & WHG09Hi02bF & $0.845 \pm 0.003$ & $0.566 \pm 0.012$ & $0.847 \pm 0.024$ & $0.568 \pm 0.005$ & $0.064 \pm 0.000$ \\
\hline $4689 \mathrm{bH} *$ & WHG09Hi02bH* & $0.671 \pm 0.005$ & $0.419 \pm 0.004$ & $0.738 \pm 0.002$ & $0.355 \pm 0.005$ & $0.101 \pm 0.003$ \\
\hline $4690 \mathrm{bF}$ & WHG09Hi03bF & $0.777 \pm 0.004$ & $0.533 \pm 0.002$ & $0.806 \pm 0.013$ & $0.495 \pm 0.008$ & $0.100 \pm 0.000$ \\
\hline $4690 \mathrm{bH}^{*}$ & WHG09Hi03bH* & $0.630 \pm 0.001$ & $0.372 \pm 0.006$ & $0.679 \pm 0.002$ & $0.303 \pm 0.005$ & $0.180 \pm 0.003$ \\
\hline $4691 \mathrm{bF}$ & WHG09Hi04bF & $0.734 \pm 0.005$ & $0.551 \pm 0.004$ & $0.829 \pm 0.003$ & $0.571 \pm 0.009$ & $0.066 \pm 0.006$ \\
\hline 4691bH* & WHG09Hi04bH* & $0.550 \pm 0.003$ & $0.377 \pm 0.007$ & $0.640 \pm 0.010$ & $0.320 \pm 0.002$ & $0.170 \pm 0.001$ \\
\hline $4692 \mathrm{bF}$ & WHG09-4Hi01bF & $0.794 \pm 0.009$ & $0.624 \pm 0.002$ & $0.856 \pm 0.008$ & $0.595 \pm 0.005$ & $0.060 \pm 0.001$ \\
\hline $4692 \mathrm{bH}^{*}$ & WHG09-4Hi01bH* & $0.576 \pm 0.003$ & $0.385 \pm 0.002$ & $0.639 \pm 0.017$ & $0.258 \pm 0.003$ & $0.241 \pm 0.008$ \\
\hline $4693 \mathrm{bF}$ & WHG09-4Hi02bF & $0.776 \pm 0.002$ & $0.556 \pm 0.009$ & $0.827 \pm 0.025$ & $0.511 \pm 0.007$ & $0.102 \pm 0.007$ \\
\hline $4693 \mathrm{bH} *$ & WHG09-4HiO2bH* & $0.643 \pm 0.001$ & $0.393 \pm 0.003$ & $0.672 \pm 0.005$ & $0.326 \pm 0.004$ & $0.194 \pm 0.011$ \\
\hline $4694 \mathrm{bF}$ & WHG09-4Hi03bF & $0.855 \pm 0.008$ & $0.447 \pm 0.009$ & $0.822 \pm 0.000$ & $0.526 \pm 0.001$ & $0.139 \pm 0.010$ \\
\hline 4694bH* & WHG09-4HiO3bH* & $0.683 \pm 0.004$ & $0.308 \pm 0.002$ & $0.635 \pm 0.005$ & $0.288 \pm 0.006$ & $0.235 \pm 0.008$ \\
\hline $4695 \mathrm{bF}$ & WHG09-4Hi04bF & $0.870 \pm 0.014$ & $0.443 \pm 0.004$ & $0.823 \pm 0.015$ & $0.527 \pm 0.003$ & $0.161 \pm 0.007$ \\
\hline $4695 \mathrm{bH}^{*}$ & WHG09-4Hi04bH* & $0.709 \pm 0.000$ & $0.324 \pm 0.001$ & $0.651 \pm 0.004$ & $0.294 \pm 0.004$ & $0.211 \pm 0.002$ \\
\hline
\end{tabular}

Table 9. Summary of sample details, dosimetry, equivalent doses, and sample ages. Dose rates are based on the conversion of the radioisotope concentrations, gamma dose rate from Nal spectrometry, cosmic dose rate calculated from the depth of the samples and an internal dose to quartz of $0.06 \pm 0.02 \mathrm{~Gy} / \mathrm{ka}$. The grain size for all samples was $180-250 \mu \mathrm{m}$. Burial depth was $34 \mathrm{~m} \pm 2 \mathrm{~m}$.

\begin{tabular}{|l|r|r|r|r|r|l|l|l|l|}
\hline Sample & $\mathrm{N}$ & $\mathrm{K}(\%)$ & $\mathrm{U}(\mathrm{ppm})$ & $\mathrm{Th}(\mathrm{ppm})$ & $\begin{array}{l}\text { Water } \\
\text { Content }\end{array}$ & $\begin{array}{l}\text { Cosmic dose } \\
\text { rate }(\mathrm{Gy} / \mathrm{ka})\end{array}$ & $\begin{array}{l}\text { Total dose } \\
\text { (Gy/ka) }\end{array}$ & De (Gy) & Age (ka) \\
\hline WHGE1 01 & 11 & 0.86 & 2 & 5.25 & $18 \%$ & $0.06 \pm 0.02$ & $1.37 \pm 0.15$ & $113 \pm 19$ & $82 \pm 17$ \\
\hline WHGE1 02 & 20 & 0.73 & 1.83 & 4.08 & $18 \%$ & $0.06 \pm 0.02$ & $1.19 \pm 0.13$ & $120 \pm 16$ & $101 \pm 17$ \\
\hline WHGE1 03 & 21 & 0.53 & 1.79 & 2.52 & $18 \%$ & $0.06 \pm 0.02$ & $0.93 \pm 0.10$ & $116 \pm 11$ & $125 \pm 18$ \\
\hline
\end{tabular}


Table 10. Revised lithostratigraphy of County Durham.

\begin{tabular}{|c|c|c|c|c|c|c|c|}
\hline & Name & Stratotype & Sedimentology & Genesis & Provenance & Chrono-stratigraphy & $\begin{array}{l}\text { Regional } \\
\text { Correlatives }\end{array}$ \\
\hline \multirow{5}{*}{$\begin{array}{l}\text { The East } \\
\text { Durham } \\
\text { Formation }\end{array}$} & $\begin{array}{l}\text { The } \\
\text { Horden } \\
\text { Member }\end{array}$ & $\begin{array}{l}\text { Upper } \\
\text { diamicton } \\
\text { at Warren } \\
\text { House Gill }\end{array}$ & $\begin{array}{l}\text { LFA } 5 \\
\text { Upper } \\
\text { stone-rich } \\
\text { diamicton, } \\
\text { massive }\end{array}$ & \multirow[t]{2}{*}{ Subglacial till } & \multirow[t]{2}{*}{$\begin{array}{l}\text { Scotland } \\
\text { and } \\
\text { northern } \\
\text { Britain }\end{array}$} & MIS 2 & $\begin{array}{l}\text { Skipsea } \\
\text { Member }\end{array}$ \\
\hline & & & & & & Late Weichselian & $\begin{array}{l}\text { Bolders } \\
\text { Bank Fm }\end{array}$ \\
\hline & $\begin{array}{l}\text { The } \\
\text { Peterlee } \\
\text { Member }\end{array}$ & $\begin{array}{l}\text { Middle } \\
\text { gravels at } \\
\text { Blackhall } \\
\text { Rocks } \\
\end{array}$ & $\begin{array}{l}\text { Poorly to } \\
\text { well-sorted } \\
\text { sands and } \\
\text { gravels }\end{array}$ & $\begin{array}{l}\text { Proglacial } \\
\text { outwash }\end{array}$ & $\begin{array}{l}\text { Scotland } \\
\text { and } \\
\text { northern } \\
\text { Britain } \\
\end{array}$ & $\begin{array}{l}\text { MIS 2; Late } \\
\text { Weichselian }\end{array}$ & \\
\hline & & & $\begin{array}{l}\text { Red sands at } \\
\text { Warren House } \\
\text { Gill (LF 4a) }\end{array}$ & & & & \\
\hline & $\begin{array}{l}\text { The } \\
\text { Blackhall } \\
\text { Member }\end{array}$ & $\begin{array}{l}\text { Lower } \\
\text { diamicton } \\
\text { at } \\
\text { Blackhall } \\
\text { Rocks }\end{array}$ & $\begin{array}{l}\text { LFA } 3 \\
\text { Lower } \\
\text { stone-rich } \\
\text { diamicton, } \\
\text { massive to } \\
\text { laminated, } \\
\text { containing } \\
\text { tectonised } \\
\text { sand beds. }\end{array}$ & $\begin{array}{l}\text { Ice-marginal } \\
\text { subglacial } \\
\text { traction till }\end{array}$ & $\begin{array}{l}\text { Scotland } \\
\text { and } \\
\text { northern } \\
\text { Britain }\end{array}$ & 80 to $40 \mathrm{ka} \mathrm{BP}$ & $\begin{array}{l}\text { Middle till } \\
\text { at Warren } \\
\text { House Gill }\end{array}$ \\
\hline $\begin{array}{l}\text { The Easingt } \\
\text { Formation }\end{array}$ & & $\begin{array}{l}\text { Calcreted } \\
\text { gravels in } \\
\text { Shippersea } \\
\text { Bay }\end{array}$ & $\begin{array}{l}\text { Well-sorted, } \\
\text { bedded, } \\
\text { rounded sands } \\
\text { and gravels }\end{array}$ & $\begin{array}{l}\text { Interglacial } \\
\text { beach }\end{array}$ & $\begin{array}{l}\text { Local and } \\
\text { from } \\
\text { underlying } \\
\text { sediments }\end{array}$ & MIS 7 & - \\
\hline The & $\begin{array}{l}\text { Whitesides } \\
\text { Member }\end{array}$ & $\begin{array}{l}\text { Beige Silts } \\
\text { at Warren } \\
\text { House Gill }\end{array}$ & $\begin{array}{l}\text { LFA } 2 \\
\text { Beige silts, } \\
\text { some } \\
\text { deformed } \\
\text { laminations, } \\
\text { foraminifera } \\
\text { present. }\end{array}$ & $\begin{array}{l}\text { Estuarine } \\
\text { silts }\end{array}$ & $\begin{array}{l}\text { Local and } \\
\text { from } \\
\text { underlying } \\
\text { sediments }\end{array}$ & - & - \\
\hline $\begin{array}{l}\text { House } \\
\text { Formation }\end{array}$ & $\begin{array}{l}\text { Ash Gill } \\
\text { Member }\end{array}$ & $\begin{array}{l}\text { Basal } \\
\text { diamicton } \\
\text { at Warren } \\
\text { House Gill }\end{array}$ & $\begin{array}{l}\text { LFA } 1 \\
\text { Grey } \\
\text { stone-poor } \\
\text { diamicton, } \\
\text { sand } \\
\text { laminations, } \\
\text { bivalve } \\
\text { fragments }\end{array}$ & $\begin{array}{l}\text { Glaciomarine } \\
\text { rainout } \\
\text { diamicton }\end{array}$ & $\begin{array}{l}\text { Mixed } \\
\text { Scottish, } \\
\text { English, } \\
\text { and North } \\
\text { Sea }\end{array}$ & MIS 8 to 12 & $\begin{array}{l}\text { Briton's } \\
\text { Lane Sand } \\
\text { and Gravels } \\
\text { or } \\
\text { Bridlington } \\
\text { Member? }\end{array}$ \\
\hline
\end{tabular}

